\title{
Textiles teñidos por amarras del Norte Grande de Chile
}

Bárbara Cases C. ${ }^{2}$ y Carolina Agüero P. ${ }^{3}$

\begin{abstract}
RESUMEN
En este trabajo se dan a conocer prendas realizadas por la técnica de tintorería de "teñido por amarra" provenientes de sitios arqueológicos del Norte Grande de Chile. Su aparición data de finales del Arcaico y comienzos del Formativo (ca. 1500-1000 AC), y su presencia continúa hasta la primera mitad del Período Intermedio Tardío (900-1200 DC). A través de un trabajo de documentación cultural y cronológica pudimos establecer por primera vez una secuencia para esta técnica, que abarca un lapso de 2700 años. Estos tejidos provienen de la zona de Arica en el extremo norte de Chile, de Tarapacá, del río Loa en su curso inferior y medio, y de los oasis de San Pedro de Atacama. Tradicionalmente esta técnica ha sido asignada a Nazca y Tiwanaku, no obstante, todas las prendas tejidas revisadas presentan ciertas particularidades coherentes con su lugar de procedencia, permitiéndonos suponer una factura local.
\end{abstract}

Palabras claves: textiles - técnica de teñido por amarra Norte Grande de Chile - períodos Arcaico, Formativo, Medio e Intermedio Tardio.

\section{ABSTRACT}

This paper presents textile pieces from archaeological sites in Northern Chile that were made by using the tie-dying technique. They first appear at the end of the Archaic and beginnings of the Formative periods (ca. 1500-1000 BC), their presence lasting until the first half of the Late Intermediate Period (900-1200 AD). We establish the first sequence for this technique (use of which spans over 2700 years) by working on its cultural and chronological documentation. These textiles come from Arica (in Chile's northernmost tip), Tarapacá, the Lower and Middle river Loa, and the oases of San Pedro de Atacama. Although this technique has been traditionally considered to be of Nazca and Tiwananku origin, all of the woven pieces that were revised reveal particularities that are coherent with the places where they come from, allowing us to suppose they are of local making.

Key words: textiles - tie-dying technique - Northern Chile - Archaic, Formative, Middle and Late Intermediate Periods.

Recibido: marzo 2004. Manuscrito revisado aceptado: julio 2004.

1 Este trabajo es resultado de los Proyectos FONDECYT 1970073 y 1990168 y fue presentado en el Simposio Internacional de Shibori (ISS'99), realizado en Santiago de Chile, entre el 2 y 5 de noviembre de 1999, en el Museo Nacional de Bellas Artes de Santiago.

\section{Introducción}

Desde el siglo pasado, los primeros investigadores que trabajaban en la arqueología del norte de Chile comenzaron a encontrar en forma ocasional, pero constante, un tipo especial de textiles arqueológicos: prendas rojas y/o azules, con decoración blanca, formando líneas, rombos o círculos, que parecían haber sido "pintados" o "desteñidos", cuya decoración no se habría logrado por el mero entrelazamiento de hilados, sino por alguna técnica más misteriosa y difícil de determinar. Se trataba de tejidos teñidos por amarras, denominadas plangi o ikat (Lindberg 1963). Piezas con similares técnicas de decoración habían sido ya descubiertas en los Andes Centrales, a partir de Chavín (700 AC). De hecho, existen textiles pintados en técnica de reserva en Carhua, en la Costa Sur del Perú fechados hacia 900-700 AC (Brugnoli y Hoces de la Guardia 1999), que despertaron la curiosidad de estudiosos del recién descubierto patrimonio textil andino.

Desde un punto de vista técnico, sabemos que se trata de textiles, la mayor parte de ellos tejidos a telar, en estructuras más bien sueltas, que han servido como soporte para la ejecución de esta variedad de teñido por reserva. Al hablar de teñido, y para establecer la diferencia con la pintura, nos referimos a la aplicación de color a una fibra por medio de la inmersión de ésta en un baño, que junto a los colorantes que serán traspasados a la tela, contiene una mezcla de mordientes y fijadores. Esta alquimia de colorantes, mordientes y fijadores más el tiempo de permanencia de la tela en el baño, permitirá que el color se haga uno con la fibra, fusionándose completamente, a diferencia de lo que sucede con la pintura, en que el pigmento se aplica

2 Universidad Internacional SEK. Av. Arrieta 10000, Peñalolén, Santiago, CHILE. Email: barbara_cases@hotmail.com

3 Instituto de Investigaciones Arqueológicas y Museo R. P. Gustavo Le Paige s. j. (IIAM), Universidad Católica del Norte. Casilla 17, Correo San Pedro de Atacama, II Región, CHILE. Email: maguero@ucn.cl 
sobre la fibra, pero siempre puede distinguirse claramente el medio del soporte. Sin duda, la tintorería de fibras debió haberse descubierto tempranamente en el mundo andino: de ello dan cuenta textiles policromos de Paracas, por mencionar sólo un ejemplo, en los que encontramos la combinación de las tonalidades naturales de la fibra, además de muchos otros colores teñidos.

Una técnica específica de tintorería son las llamadas técnicas de reserva. En ellas, se preserva el color original de la fibra por medio de la aplicación de algún material o tratamiento aislante. En el caso de materiales aislantes, se trata de cera (en cuyo caso la técnica se conoce como batik), pastas y barros o hilados (en el caso de la amarra y el ikat) o un tratamiento físico, como el pliegue o torsión de la fibra sobre sí misma, sujeta en muchos casos con hilados que amarran o atan para impedir la entrada del colorante. Como proceso de creación, todas estas técnicas requieren de una planificación "inversa" de la obra, pues donde se aplica una amarra se mantendrá aislado el color original, ya que no penetrará el colorante.

En muchas partes del mundo se han desarrollado técnicas de reserva: batik, en Africa, India e Indonesia siendo en la última donde se conoce el mayor nivel de experticia; ikat también en Indonesia, India, Tailandia y Medio Oriente y las amarras, denominadas shibori en Japón -sin duda uno de los centros de producción más sofisticados de esta técnica-, donde se ha usado de manera tradicional en las sedas para la confección de los kimono. La técnica de teñido de reserva por amarras está presente en todo el extremo oriente, incluidos China, Indonesia, Tailandia, Malasia e India, además de Africa. No obstante, esta técnica fue utilizada también en textiles no sólo en los Andes Centrales, sino también en Mesoamérica y en el norte de Chile.

Hasta ahora, los ejemplares chilenos habían sido descritos sólo ocasionalmente, por lo que gran parte del material que daremos a conocer es inédito. Desde hace ya varias décadas existe registro de textiles teñidos por amarras en el norte de Chile, formando parte de colecciones de museos y en algunos casos, provenientes de excavaciones arqueológicas. Este material ha sido esporádicamente registrado y con menos frecuencia, publicado. Recientes investigaciones arqueológicas permitieron recopilar el material existente en diversas colecciones de museos, parte del cual fue exhibido en la muestra "Amarras: El arte de teñir en los Andes prehispánicos", preparada por el Museo Chileno de Arte Precolombino, en noviembre de $1999 .{ }^{4}$

Las piezas que forman la muestra que trataremos, disponen de distintos tipos de información. En algunos casos contamos con detalles de su procedencia, incluso del contexto depositacional en que fue hallado; no obstante, esta situación no es extensiva al resto. Esto nos obligó a realizar un estudio bibliográfico de cada pieza, con el fin de documentar su posible procedencia y situación cronológica. Asimismo, nuestra aproximación a la muestra es diferencial: en algunos casos pudimos realizar un registro detallado de los atributos técnicos y decorativos de las piezas, mientras que en otros casos contamos con un registro realizado por terceros e incluso sólo con fotografías.

Queremos señalar que el total de tejidos provenientes del norte de Chile que hemos podido recopilar corresponde aproximadamente a 20 piezas (Tabla 1). Aunque no parece un número significativo, a través de un trabajo de documentación cultural y cronológica pudimos establecer por primera vez una secuencia para esta técnica, que abarca un lapso de 2.700 años (1500 AC-1200 DC). Estos tejidos provienen de la zona de Arica en el extremo norte de Chile, de Tarapacá, del río Loa en su curso inferior y medio, y de los oasis de San Pedro de Atacama (Figura 1).

\section{Arcaico Tardío al Formativo (1500 AC-500 DC)}

Las manifestaciones más tempranas de prendas teñidas por amarras se concentran principalmente en el valle de Camarones, en la I Región. La primera evidencia que hemos registrado para esta técnica corresponde a un accesorio dispuesto sobre el turbante de un infante momificado (Figura 2), ${ }^{5}$ consistente en una especie de "cola", realizada en hilado bouttonné de unos $15 \mathrm{~cm}$ de largo. Este tipo de hilado se construye por medio de torzales entre los cuales se insertan mechones de fibra o pelos

\footnotetext{
4 Las temáticas relativas al territorio chileno, dentro de dicha exhibición y catálogo, están basadas en los resultados de nuestra investigación y documentación de estas piezas.

5 Pieza ${ }^{\circ}$ 2024, depositada en el Museo Arqueológico de Santiago.
} 
TEXTILES TEÑIDOS POR AMARRAS DEL NORTE GRANDE DE CHILE

\begin{tabular}{|c|c|c|c|c|c|c|c|c|c|c|}
\hline Sitio & Referencia & $\begin{array}{c}1 \\
\text { paño }\end{array}$ & $\begin{array}{c}2 \\
\text { paños }\end{array}$ & $\begin{array}{c}4 \\
\text { módulos } \\
\text { vert. }\end{array}$ & $\begin{array}{l}\quad 4 \\
\text { módulos } \\
\text { horizont. }\end{array}$ & $\begin{array}{c}6 \\
\text { módulos }\end{array}$ & $\begin{array}{c}8 \\
\text { módulos }\end{array}$ & $\begin{array}{c}16 \\
\text { módulos }\end{array}$ & $\begin{array}{l}\text { hil./pza. } \\
\text { Bouttonne }\end{array}$ & cintas \\
\hline Azapa s/ref. & En exhibición & & & & & & & & & \\
\hline Az-6 & s/ref., reg. J. Correa & $\mathrm{x}$ & & & & & & & & \\
\hline$?$ & s/ref., reg. J. Correa & & $\mathrm{x}$ & & & & & & & \\
\hline Quiani-7 & s/ref. & & & & & & & & $\mathrm{x}$ & \\
\hline S/ref.(Cam?) & Momia $n^{\circ} 2024$ & & & & & & & & $\mathrm{x}$ & \\
\hline Cam-15 & s/ref, reg. J. Correa & & & & & & & & $\mathrm{x}$ & \\
\hline Cam-15 D & s/ref. & & & & & & & & $\mathrm{x}$ & \\
\hline Cam-8 & s/ref., reg. J. Correa & & & & & & & & & $\mathrm{x}$ \\
\hline Bajo Molle & BM 1292 & & $\mathrm{x}$ & & & & & & & \\
\hline Pica-Quisma & C-63 & & & & & $\mathrm{x}$ & & & & \\
\hline Pica-8 & $\begin{array}{l}\text { 0192, SB T14 } \\
\text { s/nº (Zlatar 1984) } \\
0316, \text { SD T5 } \\
\text { s/n (CCTC) } \\
\text { hilados }\end{array}$ & $\begin{array}{l}\mathrm{x} \\
\mathrm{x} \\
\mathrm{x} \\
\mathrm{x}\end{array}$ & & & & & & & & $\mathrm{x}$ \\
\hline Quillagua & $\begin{array}{l}\text { Tumba NE-B cf2 } \\
\text { Tumba NE-B cf } 2 \\
\text { hilados }\end{array}$ & $\begin{array}{l}\mathrm{x} \\
\mathrm{x}\end{array}$ & & & & & & & & $\mathrm{x}$ \\
\hline Chacance & $\begin{array}{l}\text { Tumba } 5 \\
\text { hilados Tumba } 1\end{array}$ & $\mathrm{x}$ & & & & & & & & $\mathrm{x}$ \\
\hline Topater & $\begin{array}{l}\text { Unidad A-1 } \\
\text { s/ref. } \\
\text { s/ref. reg. J. Baeza }\end{array}$ & $\begin{array}{l}\mathrm{x} \\
\mathrm{x}\end{array}$ & & & & & & & $\mathrm{x}$ & \\
\hline Chiu Chiu & Ref. Lindberg 1963:198 & & & & & & & & & \\
\hline San Pedro $(¿ ?)$ & $\begin{array}{l}18.298 \\
22585^{*}(\text { Renard 1997: 295) } \\
\text { 150* (Renard 1997: 295) }\end{array}$ & & & & & & & & & $\begin{array}{l}\mathrm{x} \\
\mathrm{x} \\
\mathrm{x}\end{array}$ \\
\hline Coyo Oriente & $\begin{array}{l}\text { 3945-1 } \\
3937 \text { (Oakland 1992: 233) } \\
5377 \text { (Oakland 1992: 233) }\end{array}$ & & & $\mathrm{x}$ ? & & & $\begin{array}{c}\mathrm{x} ? \\
\mathrm{x}\end{array}$ & & & \\
\hline Quitor-6 & $\begin{array}{l}2788 \\
2789 \text { (Lindberg 1963) } \\
2452 \text { (Lindberg 1963) }\end{array}$ & & & & & & & $\begin{array}{l}x \\
x \\
x\end{array}$ & & \\
\hline Quitor-2 & $1983: 15$ & & & & $\mathrm{x}$ & & & & & \\
\hline Tastil & ref. Rolandi 1973 & & & & & & & & & $\mathrm{x}$ \\
\hline Doncellas & $\begin{array}{l}\text { ref. Rolandi 1979; 42-668* } \\
\text { (Renard 1997: 296) }\end{array}$ & & & & & & & $\mathrm{x}$ & & \\
\hline Susques & 27-241* (Renard 1997: 296) & & & & & & & & & $\mathrm{x}$ \\
\hline
\end{tabular}

Tabla 1. Recopilación de prendas teñidas por amarra y su distribución. ${ }^{1}$ *Depositadas en Argentina.

1 Consideramos a las prendas no tejidas constituidas por hilados teñidos por amarra, con valor 1 en cada sitio, aunque pueda haber más. 


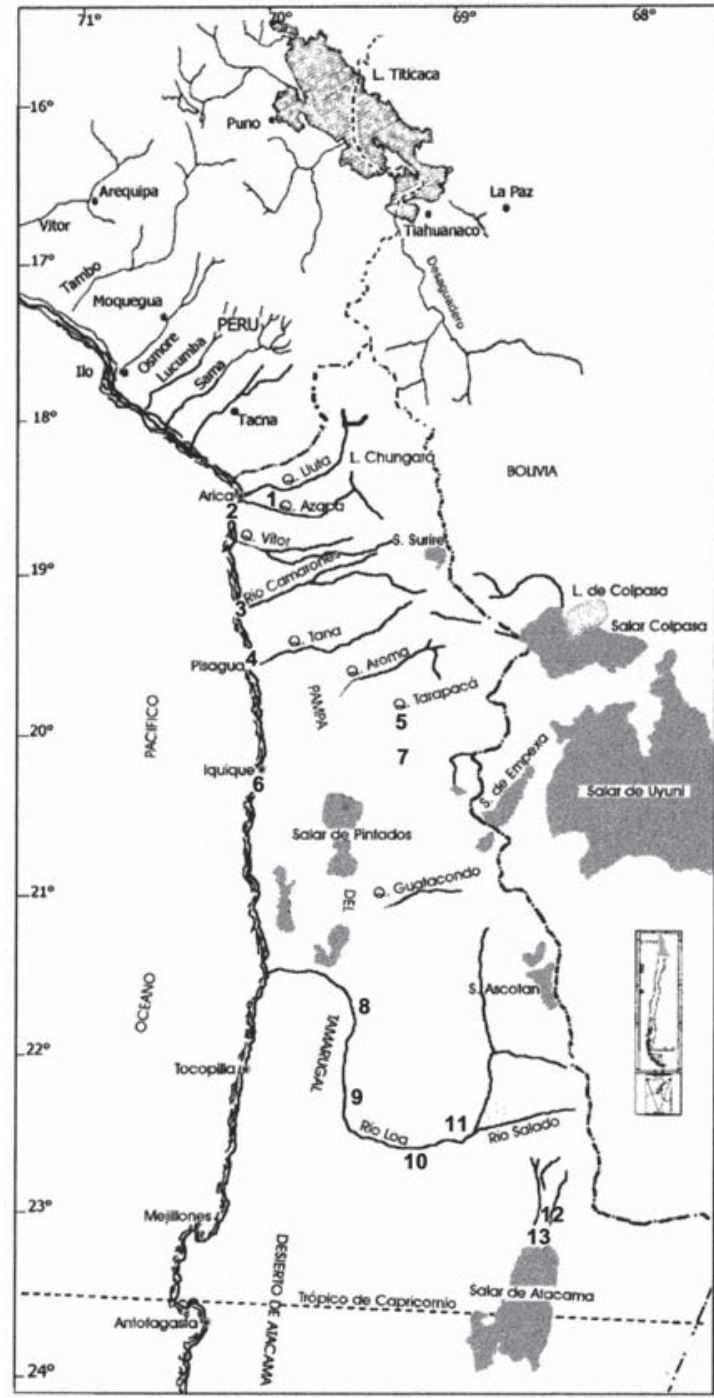

Figura 1. Mapa que muestra la distribución de las prendas teñidas por amarras: 1) Azapa-6 y 8; 2) Quiani-7; 3) Camarones-15 y 8; 4) Pisagua-D; 5) Tarapacá-40; 6) Bajo Molle; 7) Pica-8 y Pica-Quisma; 8) Quillagua (Cementerio Oriente); 9) Chacance; 10) Topater; 11) Chiu Chiu; 12) Quitor-2, 6 y 7; 13) Coyo Oriente.

de distinto largo, en forma continua, dando la apariencia de la piel de animal (Agüero 1992 Ms). Sobre este hilado se aplicaron amarras y luego se pintó, dejando listas rojas y beige, este último correspondiente al color original del hilado.

Además del turbante con este accesorio, el infante tiene otros aspectos igualmente extraordinarios. Presenta su tronco y brazos completamente cubiertos, a modo de vendaje, por fajas tejidas a telar y sus piernas, por cables o cordones en la misma modalidad. Cabe señalar que tanto el turbante, fajas y cordones, fueron realizados en hilados

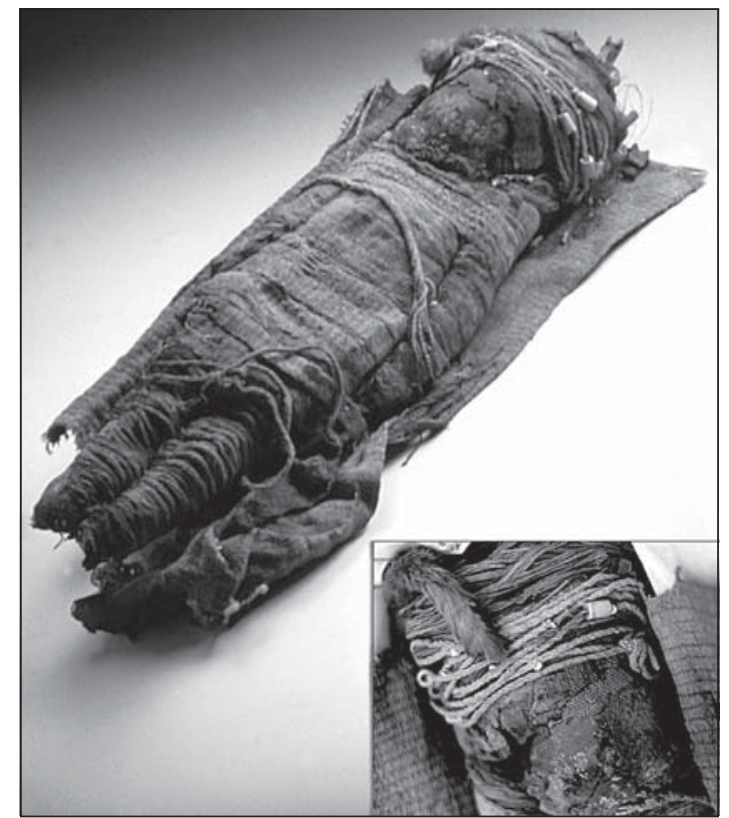

Figura 2. Momia Chinchorro Tardía (n 2024), Colección Museo Arqueológico de Santiago y detalle del hilado teñido por amarras como accesorio del turbante.

presumiblemente de fibra de camélido. ${ }^{6}$ Entre las fajas y cordones y el turbante y el cráneo se puede entrever un recubrimiento de fibra vegetal, que según informes técnicos corresponden a gramíneas; presenta palos que refuerzan o sustentan el cuerpo, situados inmediatamente bajo la piel, en contacto con la fibra vegetal: dos laterales, desde el cráneo hasta los tobillos, y uno central que sustentaría el cráneo y la columna. El cráneo aparentemente no recibió mayor tratamiento, siendo sólo la cara la que presenta una fina máscara de barro.

Aunque desconocemos las asociaciones contextuales, esta momia cuenta con un ajuar que hemos asumido como tal, porque ingresaron al Museo Arqueológico de Santiago en forma conjunta y debido a la identidad de color, grosor, torsión, estado de conservación y materia prima de los hilados de los tejidos que envuelven el cuerpo y una manta, también de fibra animal. Esta fue realizada en ligamento torzal, al igual que una estera de fibra vegetal que compone el ajuar. La

6 Los análisis de las muestras de fibras provenientes del turbante, cordones, fajas, estera, manta y fibra vegetal que envuelven al infante los realizó E. Barrera, de la Sección Botánica del Museo Nacional de Historia Natural, Santiago. 
manta está decorada con listas verticales en hilados rojizos, del mismo color que el accesorio (Cases y Rojas 2001).

Dentro de los distintos tipos de momias Chinchorro, este párvulo parece corresponder al tipo de momias artificiales de preparación complicada con vendaje (Allison et al. 1984; Arriaza 1994, 1995). Entre los escasos registros de momias de este tipo, la mayor parte son párvulos; en ellos, el vendaje está constituido por tiras de piel que envuelven todo el cuerpo, con excepción de la cabeza y sólo ocasionalmente las piernas. En nuestro caso, se han reemplazado las tiras de piel correspondientes a tejido humano, por estructuras textiles: fajas en cuerpo y brazos y cordones en las piernas. Aunque ignoramos si tiene suturas u otro tipo de intervención, pensamos que se puede tratar de una variedad que toma elementos de las momias con vendaje y con pátina de barro, al menos en el tratamiento de la cara. ${ }^{7}$ Apoya este argumento el registro de otros casos de momias Chinchorro que no se insertan en las tipologías actualmente aceptadas. ${ }^{8}$ La similitud con las momias con vendaje la sitúa inicialmente en fechas posteriores a 2500 $\mathrm{AC} ;{ }^{9}$ no obstante, el que porte textiles -turbante, fajas y cordones- y la manta asociada, sugieren que su situación cronológica se hallaría hacia el final de la tradición Chinchorro.

Aunque no existe consenso entre los investigadores con respecto a la asociación, entre otros indicadores, de "textiles tejidos" 10 y de ajuares

7 No sabemos si puede presentar, por ejemplo, vaciado y sutura posterior de la cavidad abdominal; por lo que podemos apreciar de las extremidades y de la piel expuesta, el cuerpo no parece haber tenido mayor tratamiento que el secado o ahumado del cuerpo, tal vez por medio del uso de brasas, lo que habría dejado un color gris marengo. Esto la diferencia de otras variedades de momificación "complicada".

8 Por ejemplo, en Camarones-14, Schiappacasse y Niemeyer (1984) registran párvulos con momificación artificial, con un menor nivel de complejidad y elaboración en la preparación de los cuerpos, los que presentan sólo palos de refuerzo, peluca y mascarilla.

9 Esta fecha corresponde a una estimación hecha por Arriaza (1994, 1995) de la situación cronológica de las momias con vendaje, ya que este tipo de momias no ha sido fechada por C14.

10 Suponemos que con esta expresión Arriaza (1994, 1995) alude a textiles de fibra animal tejidos a telar, ya que las esteras en ligamento torzal en fibra vegetal también corresponden a textiles tejidos, aunque no en un telar que suponga el levantamiento de lizos. numerosos con las momias Chinchorro, hay evidencia que sí apunta en esa dirección. ${ }^{11}$ De hecho, en Camarones-15 existen fajas tejidas a telar y mantas confeccionadas en la misma técnica que las esteras, incluso en hilados que mezclan pelos y lana de camélido, usando hilados de tonalidad rojiza (Ulloa, en Rivera et al. 1974). En relación a las mantas mencionadas, se trataría de piezas realizadas en fibra de camélido en ligamento torzal, con cadeneta estructural en el encabezamiento de urdimbre y luego dos corridas de tramas en torzal, que hemos reconocido, además, en los sitios formativos de Tarapacá-40 y Pisagua-D (Agüero 1995; Agüero y Cases 2004). La manta que tiene nuestra momia corresponde a la variante decorada de este tipo. Por otra parte, existe un infante similar envuelto sólo en fibra vegetal proveniente de Camarones-15, lo que nos inclina a pensar que esta momia también provendría de ahí. $^{12}$

La ausencia de textiles asociados a momias Chinchorro podría deberse sólo a un problema de registro o a una variación local. En efecto, en Ilo, Perú, se han detectado textiles con descripciones similares a las fajas que presenta nuestro párvulo, e incluso uno de ellos en ligamento torzal, realizado en algodón y fibra de camélido, asociados a momias Chinchorro, con ajuar más numeroso, y fechas tan tempranas como 5800 y 1800 AC relacionadas a los hallazgos (Torres et al. 1990; Wise 1995).

De este modo, la información expuesta hasta aquí nos permite afirmar que esta momia pertenece a la tradición Chinchorro en su fase más tardía, con una posición cronológica entre 1500 y 1000 AC, prácticamente traslapándose con los inicios del Formativo.

Esta apreciación se ve apoyada por el hallazgo también en Camarones-15 de un fragmento de faldellín de aproximadamente $1 \mathrm{~m}$ de largo. ${ }^{13} \mathrm{La}$ pieza se realizó en hilados bouttonné en fibra de camélido; los flecos se habrían montado como

\footnotetext{
11 Arriaza $(1994,1995)$ prácticamente lo desecha de plano, mientras que Standen (en Arriaza 1994) señala el incremento de los ajuares Chinchorro en sus momentos más tardíos.

12 Depositado en el Museo Arqueológico San Miguel de Azapa (MASMA) de la Universidad de Tarapacá (M. Santos, com. pers. 1997).

13 Depositado en el MASMA y registrado con el $n^{\circ} 9$.
} 
urdimbre, siendo sujetos por dos cables que funcionan como pasadas de trama, dejando que los hilados una vez sueltos se retuerzan. Los hilados que se usaron fueron teñidos en esta técnica de reserva, dejando, al igual que el accesorio de la momia Chinchorro, listas rojas sobre fondo beige natural.

Aunque no contamos con información contextual, un fechado de 890 AC para el sitio (Muñoz et al. 1991), nos permite asignarlo al Formativo Temprano. También se han detectado hilados bouttonné teñidos por amarras en Quiani-7 (Dauelsberg 1974) y Camarones 15-D (Agüero 1994). A su vez, el tipo de hilado en que se confeccionó la pieza ha sido bien documentado para este período (Agüero y Cases 2004) y sabemos que al menos un hilado teñido por amarras se ha registrado también en el cementerio Topater-1, en el Loa Medio, ${ }^{14}$ sitio que es considerado un enclave de tradiciones foráneas y que cuenta con una media de fechados de 200-300 DC, que lo sitúan en el Formativo Tardío (Thomas et al. 1995). Por otra parte, la forma de construcción del faldellín es idéntica a la que hemos observado en ejemplares fragmentados del mismo sitio (Agüero y Cases 2004).

\section{Período Medio (500-1000 DC)}

A pesar de la relativa abundancia de datos existentes para momentos más tempranos, en el extremo norte de Chile encontramos en este período una total ausencia de piezas teñidas por amarras, las que sólo aparecen hacia el final. De hecho, la única pieza que hemos registrado proveniente de esta zona corresponde a un poncho tejido en un solo paño en faz de urdimbre, con flecadura estructural, en hilados de camélido, usando una trama continua. ${ }^{15}$ No presenta terminación en la abertura del cuello, excepto en el vértice mismo, donde lleva un festón anillado sencillo; tampoco tiene terminaciones en las orillas de trama. La decoración lograda por teñido de amarras consistió en una única lista horizontal blanca en la sección media del poncho y en otra de iguales características situada en la flecadura. Para lograr esta decoración, estas listas blancas

\footnotetext{
14 Registrado por J. Baeza en 1999.

15 Depositado en el MASMA y registrado por J. Correa en 1999, con el n 21 .
}

fueron amarradas antes de sumergir la pieza en un baño rojo intenso (Figura 3).

El solo hecho de que se trate de un poncho y no de una túnica (para lo cual serían necesarias costuras laterales que cerraran la pieza) sugiere el carácter intrusivo de esta prenda, ya que no es una forma habitual dentro del registro arqueológico del norte de Chile, concentrándose hasta el momento únicamente tres de ellas en el sitio Az6, a diferencia de lo que sucede en Perú, donde Paul (1983) afirma que dentro del atuendo Paracas habría existido un poncho corto. Por otra parte, la presencia de una trama continua indica que, efectivamente, se trata de una prenda de la tradición textil de Valles Occidentales, tal como lo hemos planteado en trabajos anteriores (Agüero 2000). Finalmente, y en relación a la pieza en sí, hemos observado la flecadura estructural -también con teñido por amarras- en túnicas de dos a cuatro paños realizadas en esta técnica, correspondientes al Período Medio. Es por esto que hemos estimado su situación temporal en 800-1000 DC.

Aunque sabemos que esta pieza procede del cementerio Az-6 en el valle de Azapa, no disponemos de información sobre el número de tumba ni sobre las asociaciones contextuales. En cuanto a su situación cronológica, Az-6 es un sitio de contextos asignados principalmente a Cabuza (411681 DC), habiendo también contextos Maytas Chiribaya, que están fechados entre 900-1260 DC (Espoueys et al. 1995). Estas últimas fechas

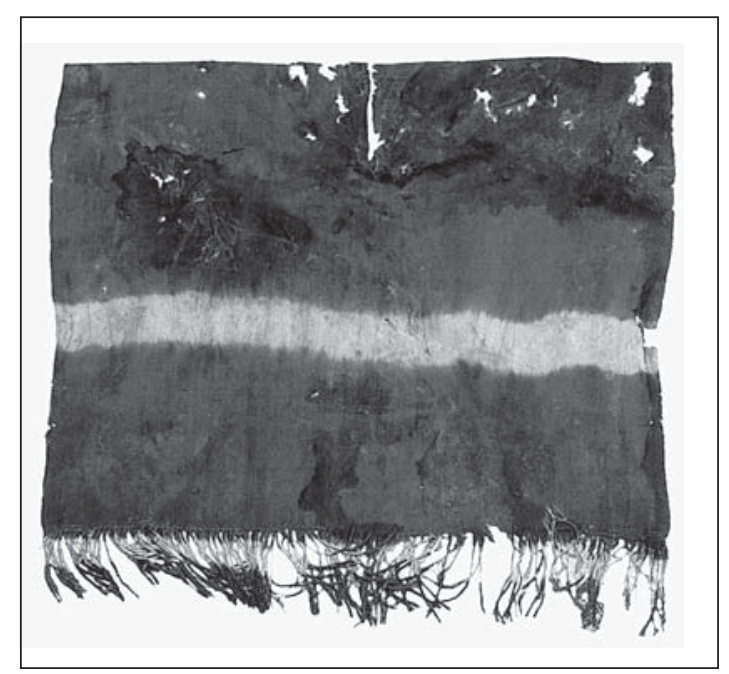

Figura 3. Poncho $s / n^{\circ}$, Az-6, Colección Museo Arqueológico San Miguel de Azapa. (*) Ver agradecimientos. 
coinciden con el rango temporal estimado por nosotras para el mencionado poncho. Cabe destacar que Maytas Chiribaya marca el inicio de la Tradición de Valles Occidentales en Azapa, la que evidencia fuertes nexos iconográficos y estilísticos con la costa sur del Perú, reforzando nuestra impresión inicial respecto a que se trataría de una pieza de carácter intrusivo.

Más al sur, en Atacama, encontramos una pieza única. Se trata de una túnica proveniente del cementerio Quitor-2. ${ }^{16}$ Es de forma rectangular, de $71 \mathrm{~cm}$ de alto por $58 \mathrm{~cm}$ de ancho, compuesta de cuatro paños tejidos en faz de urdimbre con urdimbres discontinuas en hilados de camélido, empleando tramas múltiples. Dos de estos paños son de forma cuadrada y dos rectangulares, que se disponen en la parte inferior de la pieza. La decoración se logró por medio de distintas técnicas de reserva: amarra, costura, probablemente alguna pasta o barro aislante e incluso con tramas y urdimbres discontinuas para lograr una clara definición del diseño. Luego, cada paño fue teñido en colores rojo o azul, para luego ensamblarlos de forma tal que ambas caras de la túnica alternan una parte superior de un color y la inferior del opuesto. Con estos recursos se logró crear figuras de felino en los paños cuadrados y serpiente bicéfala con fauces dentadas, en los paños rectangulares; ambas figuras tienen rombos dentro de sus cuerpos (Figura 4). La abertura del cuello no tiene terminaciones; la de los brazos está terminada en un festón anillado sencillo azul y blanco sobre la parte azul, y rojo y blanco sobre la roja. Como terminación de urdimbre lleva festón anillado sencillo. Cabe señalar que cuando estudiamos la pieza pudimos constatar que se encuentra dada vuelta: es decir, la cara que se ve actualmente corresponde a lo que habría sido el reverso de la pieza en vida.

En este caso, contamos con información fragmentaria sobre sus asociaciones contextuales: sabemos que estaba dispuesta sobre la cabeza de un individuo adulto y se ha supuesto que se trata de la túnica de un niño, debido al tamaño. No obstante, algunos atributos técnicos nos ayudan a rea-

16 Túnica no 1983:15, depositada en el Instituto de Investigaciones Arqueológicas y Museo (IIAM) de la Universidad Católica del Norte. Ha sido descrita por Torres y Conklin (1995: 88, figs. 9 y 105-107).

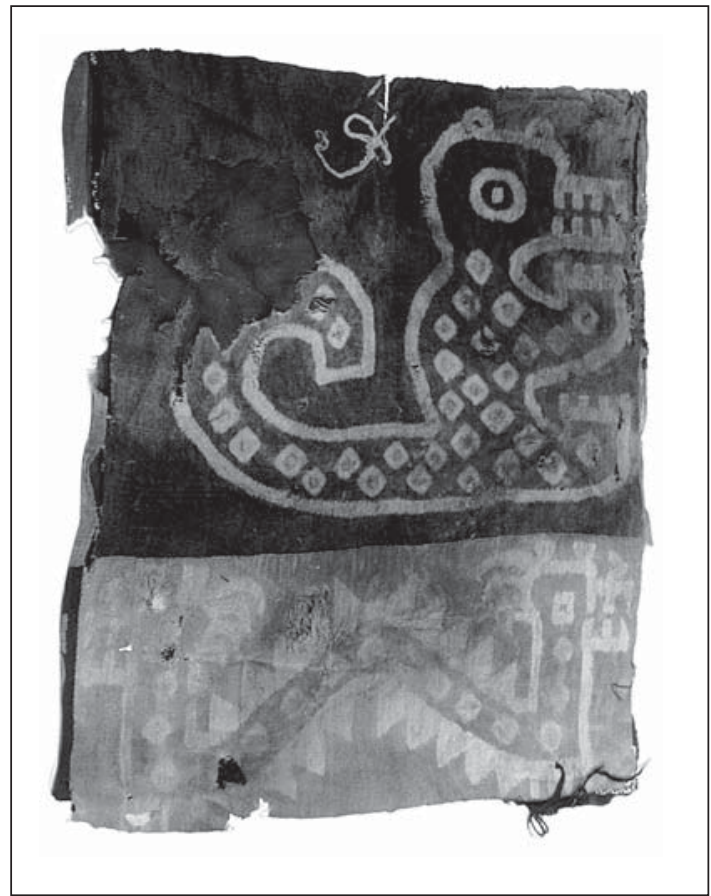

Figura 4. Túnica Aguada, Quitor-2, nº 1983: 15, Colección Museo Arqueológico R. P. Gustavo Le Paige, s. j. (*) Ver agradecimientos.

lizar su asignación cultural: la utilización de tramas múltiples y la técnica de urdimbres discontinuas la insertan dentro de la Tradición Textil de Atacama durante el Período Medio (Agüero et al. 1997; Uribe y Agüero 2002). Por otro lado, las semejanzas de las imágenes de la túnica con aquellas de la cerámica Aguada del Noroeste Argentino, situada cronológicamente en el 660 DC, sugieren que esta prenda tuvo su origen por esos años en el área trasandina (Llagostera 1995; Torres y Conklin 1995). Este vínculo estilístico resulta de sumo interés, ya que sería el único textil Aguada registrado en San Pedro de Atacama.

La mayor parte de las prendas tejidas y teñidas por amarra del Período Medio se concentra en territorio atacameño. Estas piezas corresponden a túnicas y mantas construidas por la unión de módulos rojo/azul u ocre/azul, a través de la técnica de urdimbres discontinuas. Existen túnicas con ocho cuadros de colores rojo/azul alternados (cuatro adelante y cuatro atrás); cuatro sectores de colores ocre/azul alternados horizontalmente, todas ellas con urdimbres discontinuas y una manta con 16 módulos azul/rojo y un sector central con 
motivos de cruces y escalerados, supuestamente logrados por urdimbres discontinuas. Los ejemplares provenientes de San Pedro se distribuyen en los sitios del Período Medio: Coyo Oriente, Quitor-6 y Quitor-7.

Son dos las túnicas provenientes de Coyo Oriente. Una de ellas está fragmentada y en muy mal estado, por lo que no podemos afirmar el número de módulos o paños tejidos que habría tenido, ni otros detalles relativos a sus terminaciones..$^{17} \mathrm{No}$ obstante, sabemos que presentaba una cadeneta de montaje (o estructural) y que fue tejida con tramas múltiples. La segunda está prácticamente completa, aunque frágil (Figura 5). ${ }^{18}$ Mide $71 \mathrm{~cm}$ de largo por $64 \mathrm{~cm}$ de ancho y tiene un total de ocho módulos: en cada cara tiene dos rojos y dos azules dispuestos alternadamente en relación al color en cada cara y entre las caras. Sobre cada uno de estos módulos se dispusieron nudos aproximadamente romboidales. El diseño que conforman los nudos es irregular, es decir, no existiría la misma cantidad ni disposición de nudos sobre cada uno de los módulos ni, por lo tanto, entre las caras. La flecadura, también teñida por amarra, está dispuesta en la orilla inferior y consiste en las urdimbres retorcidas, sobre las que se dispuso una cadeneta. En la abertura del cuello lleva un festón anillado sencillo en tramos blanco, azul, rojo, verde y amarillo ocre. Como unión lateral presenta puntada zigzag envuelta azul y blanco (que podría tratarse de un rojo desteñido), mientras que como unión central tiene también esta puntada, pero sólo en blanco. La abertura de los brazos presenta un festón anillado simple en tramos blanco, azul, rojo, verde y amarillo ocre. El tipo de nudo que se empleó para reservar en esta túnica no tiene precedentes ni contraparte en la muestra que hemos recopilado.

La primera de estas piezas formaba parte de la tumba 3945 y se encontraba asociada a los siguientes materiales: bolsa (contiene caracol de agua dulce; calabaza; fragmento de cerámica negra); bolsa (contiene arco de madera quebrado); bolsa (contiene fragmento de cobre, fragmento de obsidiana y cinco cuentas de malaquita); bolsa (contiene fragmentos de canastos, piel de camélido, huesos y semillas, espinas de cactus, frag-

\footnotetext{
17 Túnica n 3945-1, depositada en el IIAM.

18 Túnica $n^{\circ} 3937$, depositada en el IIAM.
}

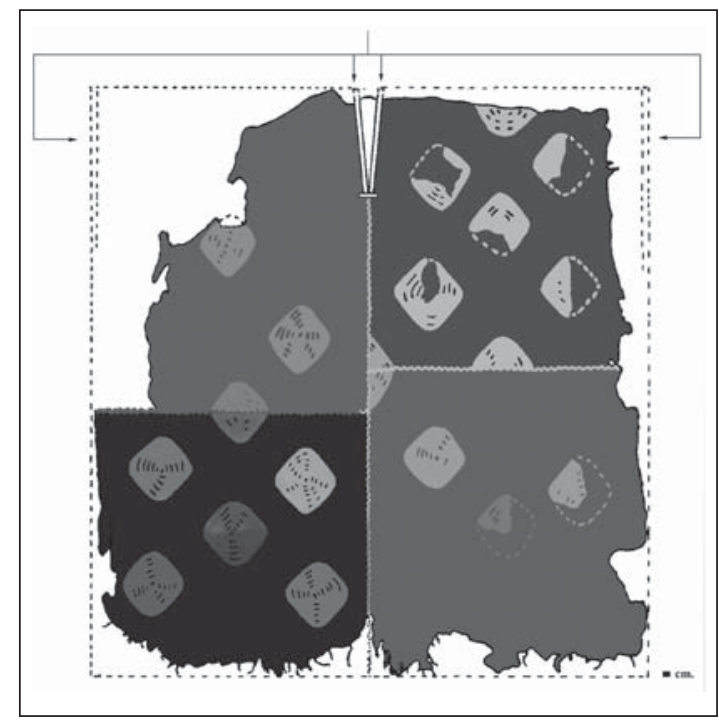

Figura 5. Túnica n 3937, Coyo Oriente, Colección Museo Arqueológico R. P. Gustavo Le Paige, s. j.

mento de cuerda roja de lana y otra de fibra vegetal); túnica 3945-2; túnica 3945-3 y dos fajas 3945-4. Oakland (1992: 328 y 1994: 110) afirma que la tumba pertenece a un individuo femenino que sólo tiene una tableta y un arco. De la pieza siguiente Oakland (1994: 328) dice que la túnica posiblemente pertenece a un individuo masculino, que también lleva puesta una túnica de su Tipo IV, un gorro anudado y un arco.

Estas túnicas muestran ciertos atributos técnicos como una cadeneta estructural en un encabezamiento de urdimbre que toma tres hilos de urdimbre y usan tramas múltiples (dos y cuatro, respectivamente), lo que las conecta con rasgos formativos y con la Tradición Textil de Atacama, respectivamente (Agüero 1998; Agüero et al. 1997). Cabe destacar que la unión efectuada en puntada zigzag envuelta en la segunda túnica la hemos observado en otras prendas del Período Medio en Azapa (asignados a Cabuza), San Pedro, y Cochabamba en Bolivia.

De este modo, no sólo por los atributos anteriores no adherimos a la idea de Oakland $(1992 ; 1994)$ de asignar a esta túnica a su estilo B (Tiwanaku), sino porque además esta autora no da razones de por qué su Tipo VI (en el cual inserta a las túnicas teñidas por amarra) sería Tiwanaku (no tiene refuerzo del vértice de la abertura para el cuello ajedrezado, ni tampoco el tipo de gorro que para 
ella sería indicador). Otra de las túnicas de su Tipo VI ( ${ }^{\circ}$ 3937) se asocia a una túnica asimétrica que asigna a su Tipo IV, el que presenta decoración por urdimbres transpuestas, técnica atacameña (Agüero $e t$ al. 1997), pero que en otro contexto se encuentra asociada a elementos Tiwanaku y a un fechado de 640 DC. Sin embargo, pensamos que esa única asociación para esa técnica (frecuente en Atacama) no es suficiente para causar el "efecto en cadena" que utiliza la autora para asignar culturalmente a Tiwanaku a una túnica teñida por amarra asociada a otra túnica decorada con urdimbres transpuestas, ni a un Tiwanaku Provincial, en virtud de la misma asociación.

En Quitor-6 encontramos una manta descrita y dibujada por Lindberg:

"Los grandes paños o túnicas encontrados con las momias 2789, 2788 y 2452 sólo se han podido conservar parcialmente, ya que se desintegraron casi totalmente al abrir los fardos funerarios. Son ejecutados en técnicas combinadas de "parches" $o$ "piezas" de colores alternados [patch-work], de gobelino enlazado [interlocked tapestry] y teñido por atados en técnica de ikat. Los parches que componen las partes laterales de la tela III de Momia 2788, Quitor-6 (Lám.II), son rectángulos de $30 \times 50 \mathrm{~cm}$, alternándose siempre una pieza de rojo venecia con una de color azul oscuro. La parte central de la tela forma una franja ancha con dibujos de escaleras que encierran cruces latinas en los colores rojo, azul oscuro, verde oscuro, beige. Tanto la técnica del gobelino enlazado como los motivos geométricos del diseño se han considerado, hasta ahora, típicos para la época Tiwanaku Epigonal y del área sur de la costa peruana, y ha sido una gran sorpresa de encontrarlos en tan extraordinarios ejemplares en plena zona atacameña. En dos telas grandes se produce, en los campos o "parches" rectangulares, un efecto muy interesante por las ataduras de la técnica ikat, y que son pequeños rombos o círculos que atraviesan la tela diagonalmente. Estos dibujos aparecen en el color beige natural de la tela, la que se ha sumergido en tintes azules o rojos, respectivamente, después de haberse efectuado las pequeñas ataduras" (1963: 198, lám. II). ${ }^{19}$

19 Manta $n^{\circ} 2788$ depositada en el IIAM. Registramos dos "piezas" o conjuntos de fragmentos con este número. Su-
Presenta las siguientes asociaciones contextuales: diademas con cuentas; capuchón sobre la cabeza; collar de malaquita o liparita; brazaletes; túnica tosca; túnica fina; túnica afelpada; costal; bolsas chicas; bolsa para equipo de rapé y brochas.

El fragmento de manta muestra como atributo técnico el uso de tramas múltiples $(n=5)$, que de inmediato la inserta dentro de la Tradición Textil de Atacama. En ésta también es frecuente encontrar las uniones laterales de las túnicas cosidas por medio de un festón simple, costura que está presente en esta pieza pero no sabemos a qué lugar podría corresponder. Según Lindberg (1963: 198) esta prenda tiene un sector central tejido en tapicería, no obstante, hemos visto diseños similares de cruces y escalerados, en bolsas de Quitor2 ( $\mathrm{s} / \mathrm{n}^{\mathrm{o}}$ y n $\left.^{\mathrm{o}} 65-2\right)$ y Quitor-6 ( $\left.\mathrm{n}^{\mathrm{o}} 2467\right)$, todos sitios del Período Medio, pero la técnica no es tapicería, sino urdimbres discontinuas.

Respecto a la asignación cultural, la prenda es, a nuestro juicio, de factura local tanto por el uso de tramas múltiples como por los motivos de cruces y escalerados, registrados únicamente en San Pedro de Atacama. Asimismo, el contexto muestra prendas atacameñas como los implementos del complejo alucinógeno y la túnica afelpada que apoyan la procedencia local de esta pieza.

Finalmente, en Quitor-7 hallamos otro fragmento, que por la disposición de los rombos teñidos por amarra y el uso de festón anillado sencillo en las orillas de trama, suponemos que corresponde a una manta similar a la anterior. ${ }^{20}$ Desconocemos sus asociaciones contextuales, pero la asignamos tentativamente a este conjunto, en virtud del argumento anterior.

\section{Período Intermedio Tardío, primera mitad (900-1200 DC)}

Para este período contamos con tres conjuntos de piezas. El primero consta de dos túnicas con flecadura estructural, construidas por dos paños tejidos en faz de urdimbre en hilados de camélido,

ponemos que uno de ellos debe corresponder al $n^{\circ} 2789$, al que hace referencia la autora y que citamos más adelante; sin embargo, ese número actualmente está asignado a una bolsa con urdimbres transpuestas.

20 Manta $^{\circ} 3137$ depositada en el IIAM. 
con una trama continua, unidos longitudinalmente por el centro de la pieza después de teñirlos separadamente en rojo y azul, de modo que el lado izquierdo y derecho de la pieza son de distinto color (Figura 6). Cada paño se amarró previo al teñido, dejando cinco filas de tres círculos con un rombo en el centro, en cada cara.

El segundo está compuesto por siete piezas completas y algunos fragmentos que corresponden al Tipo 21 de túnicas definidas por Agüero (1998: 122, fig. 20 y 125, fig. 37) para la primera mitad del Período Intermedio Tardío y, sin dudas, es el grupo más coherente. Se trata de túnicas constituidas por dos partes: cuerpo y flecadura. Ambas fueron realizadas en forma independiente y corresponden a tejido plano en faz de urdimbre en hilados de camélido, utilizando una trama continua. La flecadura consiste en $1 \mathrm{a} 3 \mathrm{~cm}$ de tejido en faz de urdimbre, para luego dejar sueltas las urdimbres restantes, las que por retorsión forman los flecos. Ambas partes se decoraron por la reserva de amarra, generando en el cuerpo tres filas de cuatro rombos blancos con un círculo central sobre fondo azul y en la flecadura una lista blanca sobre el fondo rojo (Figura 7). Una vez teñidas, ambas piezas se unieron por medio de un encandelillado. Dentro del conjunto existe una

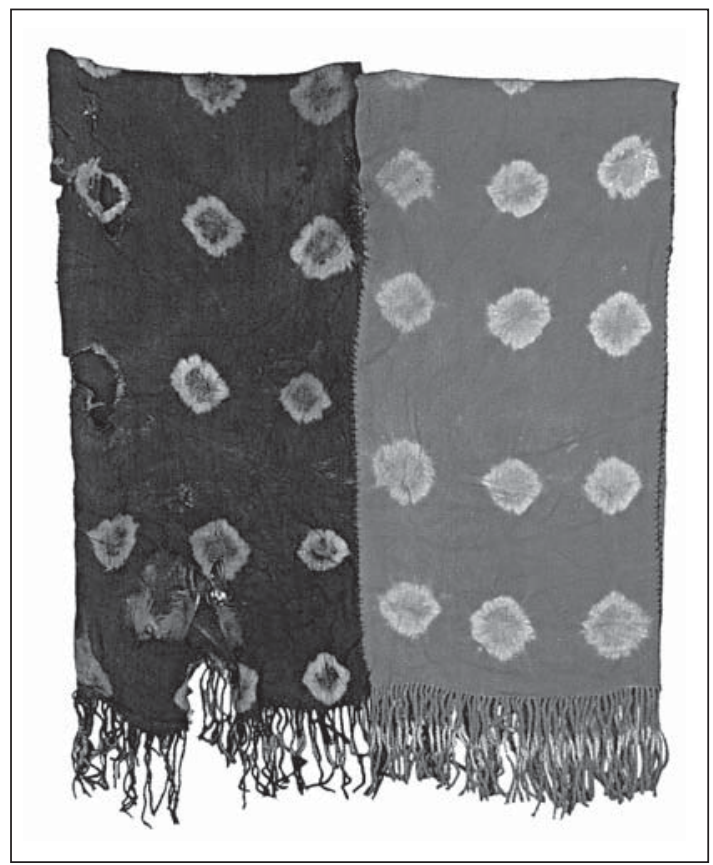

Figura 6. Túnica BM 1292, Bajo Molle, Colección Nielsen, Museo Regional de Iquique. (*) Ver agradecimientos. excepción, que veremos más adelante, en que el cuerpo y la flecadura son de color rojo, y como decoración presenta sólo un rombo generado por esta técnica de reserva.

El tercero se compone de piezas compuestas por tres a cuatro hilados -generalmente cables- de título más bien grueso, en fibra de camélido, dispuestos en forma paralela y que se encuentran unidos mediante hilados finos a modo de costura. Renard (1997: 295) denomina "cinta plana" a este tipo de estructuras. Luego, estas cintas fueron teñidas por amarras en tramos, en uno o más colores, usualmente rojo, azul o amarillo ocre (Figura 8).

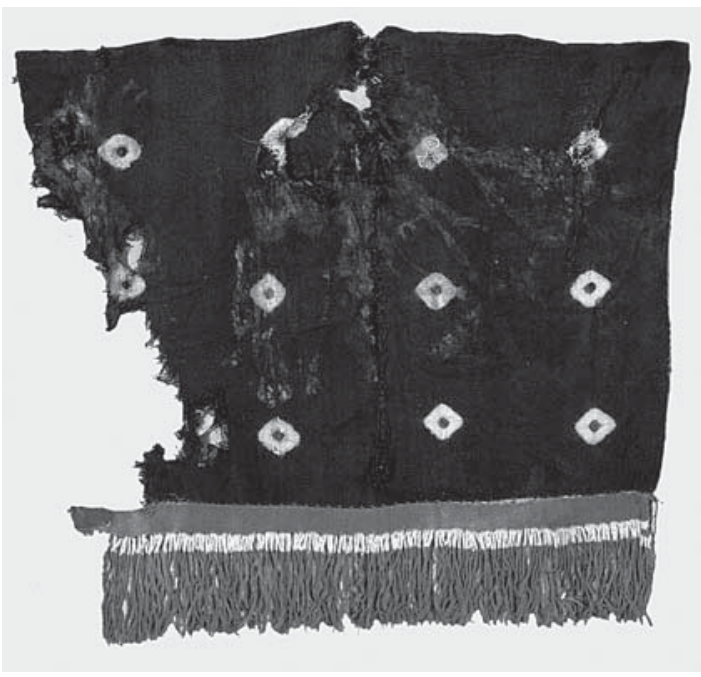

Figura 7. Túnica $s / n^{\circ}$, Pica- 8 , Colección Instituto de Investigaciones Antropológicas, Universidad de Antofagasta. (*) Ver agradecimientos.

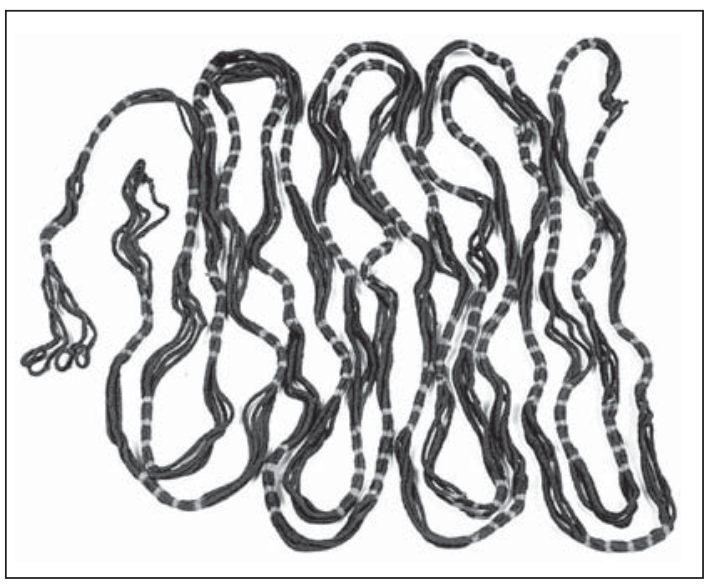

Figura 8. "Cinta" n 18.298, Colección Museo Arqueológico R. P. Gustavo Le Paige, s. j. (*) Ver agradecimientos. 
Del primer conjunto, uno proviene del extremo norte de Chile, que también en este período tiene pocas referencias para el uso de esta técnica. Se trata de una túnica trapezoidal, compuesta por dos paños tejidos en faz de urdimbre, usando una trama continua y con flecadura estructural, unidos en el centro por un encandelillado. ${ }^{21}$ Se desconocen sus asociaciones contextuales. Su forma trapezoidal y el uso de una trama continua indica que pertenece a la Tradición Textil de Valles Occidentales, que se inicia en Azapa por el 800 DC, marcando los inicios del Período Intermedio Tardío (Agüero 2000).

Otra prenda es una túnica procedente de la región de Tarapacá, del sitio costero Bajo Molle, al sur de Iquique, y forma parte de la exhibición permanente del Museo Regional de Iquique, donde se encontraba dada vuelta, al igual que la túnica con iconografía Aguada. ${ }^{22}$ La túnica de Bajo Molle mide $81 \mathrm{~cm}$ de ancho por $97 \mathrm{~cm}$ de largo, y está compuesta de dos paños, con flecadura estructural, unidos por el centro de la pieza. Tanto la unión central como las laterales fueron realizadas con puntada "espina de pescado". La abertura de los brazos tiene un festón sencillo, mientras que la abertura del cuello no tiene terminaciones.

Según el inventario del museo, de la tumba se obtuvo un cráneo con casco de cuero, un adorno de plumas y un paño sobre el rostro, junto a: fragmento de túnica café-rojo; fragmento de túnica café; faja con decoración bordada formando rombos policromos; bolsa policroma listada; bolsa policroma decorada; bolsa decorada con pelo humano; costal listado en tonos café naturales; paño café listado con cordelillos; рисо de calabaza; puco de cerámica; cerámica modelada antropomorfa; cerámica pequeña, sin asa; plato de cestería decorado; carcaj de cuero de zorro con adorno rojo con nueve flechas; adorno metálico; adorno de cuero con lana; tres cueros con lana e hilos; atado de lana y plumas.

Por una parte, sus dimensiones (larga y holgada) y el uso de una trama continua la emparentan con aquella del MASMA y la insertan dentro de la

\footnotetext{
21 S/n ${ }^{\circ}$, MASMA. Fue registrada por J. Correa durante 1999.

22 BM 1292. Museo Regional de Iquique (Colección Nielsen). Una descripción y un dibujo de la pieza fueron publicados por Moragas (1995: 71 y lam. 3, fig. 2).
}

Tradición Textil de Valles Occidentales. Además de una fecha de 1258 DC (Moragas 1995: 72), el contexto de la túnica muestra únicamente elementos asignables al Período Intermedio Tardío que, según Moragas (1995: 71), corresponderían a "un personaje de alta jerarquía". Entre éstos tenemos el casco de cuero de lobo marino con adorno de lana y penacho de plumas de parina. Registros de cascos de este tipo existen en el sitio Los Verdes, en contextos correspondientes al Intermedio Tardío (Sanhueza 1985) y en la tumba 5 de Chacance-2, en el Loa Medio. Por otra parte, el motivo de ganchos y escalerados naranja y blanco sobre fondo negro de la bolsa confeccionada en técnica de anudado y afelpado, lo encontramos en una inkuña del sitio Az-8 en el valle de Azapa, y en una túnica de Pica-8, ambos sitios del Período Intermedio Tardío. La cerámica asociada, es del tipo Chiza Modelado (Moragas 1995: lám. 3, fig. 3), para la cual se cuenta con una fecha TL de $1230 \pm 40 \mathrm{DC}$, de un gollete con modelado antropomorfo proveniente de una tumba disturbada del sitio "ex asentamiento Manuel Rodríguez", ubicado en el faldeo sur de la localidad de Cuya, en el valle de Camarones (Schiappacasse et al. 1991: 47-48, Lám. II d); coherentemente, con frecuencia se asocia al tipo cerámico Pica-Charcollo que cuenta con fechas de 1055 DC y 1110 DC (Agüero et al. 1997).

Referencias a otros contextos de Bajo Molle recuperados por Anker Nielsen, también los aporta Moragas (1995: 71), quien afirma que los cementerios corresponderían en su mayoría al Período Intermedio Tardío. Respecto a la textilería, señala que ésta presenta "rasgos Tiwanaku que Ulloa (1982 a y b) ha descrito para la fase Cabuza, junto a otras evidencias del Desarrollo Regional." Entre los primeros estarían: un gorro de cuatro puntas de colores naturales con diseños escalerados; bolsasfaja listadas; túnicas con listados laterales policromos y uniones cosidas con puntada "espina de pescado" o bordados en puntada satín creando ajedrezados. Cabe destacar que el gorro, aunque con colores y motivos distintos, se inscribe por su forma y motivos geométricos dentro del Tipo I. 1 Policromo Geométrico de Sinclaire (1998: 174) el que cronológicamente se situaría en el 850 \pm 90 DC. Por su parte, la puntada "espina de pescado" la encontramos en un gran número de túnicas (sobre todo monocromas) desde el Período Medio en adelante, y la puntada satín ocurre en varios tipos de túnicas de Pica-8 (Agüero 1998). 
Moragas (1995: 71) también afirma que en los textiles de Bajo Molle dominan los tonos de verdes, azules y rojos, habiendo también morado y amarillo, que destacan diseños de ganchos. Estos ganchos son motivos frecuentes en los bordados laterales de las túnicas de Pica-8, Pisagua (Cementerio C) y Cementerio Oriente (Qui-01) de Quillagua, todos los cuales corresponden a la primera mitad del Período Intermedio Tardío. Finalmente, entre los elementos de influencia Tiwanaku, la autora describe la técnica de teñido por amarra, aunque luego acota que, entre los elementos propios del Intermedio Tardío, se contarían unos pocos flecos en bolsas y túnicas, entre las que se cuenta la túnica que aquí nos interesa.

En síntesis, la fecha del contexto nos resulta un poco tardía si consideramos el resto de los datos tales como la cerámica y las similitudes con el cementerio Pica-8, así como también aquellos provenientes del resto de los cementerios de Bajo Molle, todos los cuales están en un rango que se ubica entre el 800 y el 1100 DC, sugiriendo una asignación cronológica para la pieza dentro de la primera mitad del Período Intermedio Tardío.

Una tercera túnica proviene de Pica-Quisma, en la zona de quebradas intermedias ubicadas en la región de Tarapacá. ${ }^{23}$ Es de forma rectangular y mide $1 \mathrm{~m}$ de ancho por $64 \mathrm{~cm}$ de alto. Se confeccionó con seis paños de tejido plano en faz de urdimbre con urdimbres discontinuas, con flecadura estructural, usando cuatro tramas. Cada paño se amarró dejando dos filas de tres rombos con círculo central y luego se tiñó: tres en azul, dos en rojo y uno en naranja (quizás se trate de fotodegradación). Cuatro de estos paños se sitúan en el anverso y reverso de la pieza (dos a cada lado), mientras que los dos restantes pasan sobre los hombros y son utilizados como parte superior en ambas caras de la túnica (Figura 9). Los paños fueron unidos en el centro por medio de un encandelillado, al igual que las uniones laterales. La abertura del cuello tiene restos de un festón anillado sencillo, terminación presente también en la abertura para los brazos. Esta prenda fue hallada en superficie, cerca de un cuerpo procedente de una tumba alterada que tenía pues-

23 Túnica C-63 / Museo Regional de Iquique. Una descripción y un dibujo de la pieza fueron publicados por Moragas (1995: lám. 3, fig. 2).

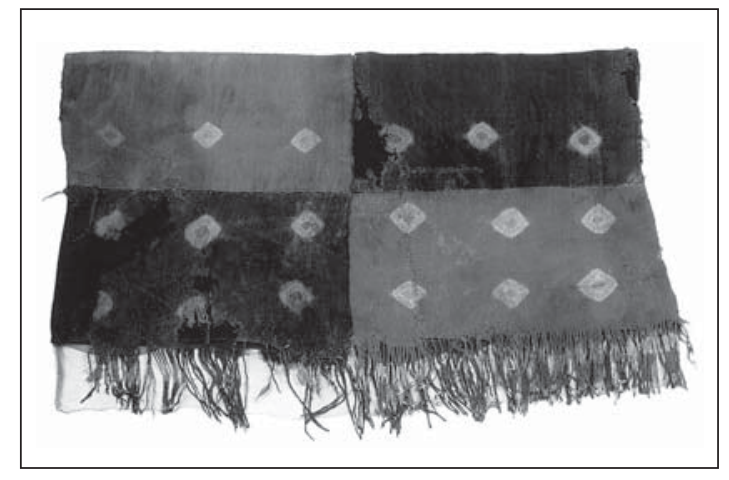

Figura 9. Túnica C-63, Pica-Quisma, Colección Museo Regional de Iquique. (*) Ver agradecimiento.

ta una túnica café con decoración a los lados. Al parecer, la tumba era de las pocas que estaban marcadas con piedras blancas, lo que para Moragas significa que pertenecía a un personaje de alta jerarquía "equivalente al registrado en Bajo Molle" (1995: 72).

El cementerio Pica-Quisma se ubica en la quebrada de Quisma, $5 \mathrm{~km}$ más arriba que Pica-8, y tiene dos sectores, uno formativo y otro correspondiente al llamado Complejo Pica-Tarapacá del Intermedio Tardío, pero según Moragas (1995: 72) muestra influencias Tiwanaku que se reflejarían principalmente en la textilería, no habiendo -al menos dentro de lo que se pudo observar en un momento posterior a la profanación del cementerio- un sector Tiwanaku delimitado. La autora acota que algunos elementos de Pica-Quisma también se registran en Bajo Molle, tales como: túnicas rectangulares de colores naturales con uniones laterales cosidas con festón sencillo, "espina de pescado" o bordadas con puntada satín con colores azul, verde, rojo y café oscuro; túnicas con listas laterales policromas rojo, negro, amarillo y verde; motivos ajedrezados en amarillo y café. La cerámica característica es la llamada PicaCharcollo (1055 DC y 1110 DC) que se distribuye en todo el territorio de Tarapacá hasta el Loa por el sur (Ayala y Uribe 1996).

La túnica difiere en dimensiones y factura de aquella de Bajo Molle y Azapa, y el uso de tramas múltiples la acercan a aquellas de San Pedro de Atacama; no obstante, esta túnica tiene la particularidad de estar compuesta por seis módulos. Además, las urdimbres de los módulos no están unidos con enlace dovetailed 1:1, como la mayor 
parte de las túnicas teñidas por amarra de San Pedro de Atacama, sino que cada enlace toma un número mayor de urdimbres.

Los datos anteriores nos llevan a pensar que la túnica -sin duda de origen atacameño-, podría haber sido reutilizada o adaptada por gente de Tarapacá, lo que explicaría su extraña forma (muy corta) así como también el contexto supuestamente más tardío en que se encontró, en relación a las piezas teñidas por amarra de San Pedro de Atacama.

El segundo conjunto de piezas que mencionamos para este período es uno de los más consistentes y mejor documentados de la muestra. Se han hallado ejemplares tanto en Pica-8 (Tarapacá) como en Chacance y Quillagua (Loa Medio e Inferior, respectivamente). Por la forma trapezoidal, el uso de una trama continua y distribución, estas túnicas han sido asignadas al Complejo Pica-Tarapacá, dentro de la Tradición de Valles Occidentales, y su situación cronológica estaría entre 900-1200 DC, en virtud de los fechados y asociaciones disponibles

Los dos primeros ejemplares registrados provienen del Contexto Funerario 2 (NE-B) del Cementerio Oriente (Qui-01) de Quillagua. ${ }^{24}$ Se hallaron formando parte de un entierro colectivo en el cual se depositaron tres individuos adultos y un infante, cada uno de los cuales presentó su propio ajuar funerario. Los cuerpos se encontraban en posición sentada y decúbito lateral con las piernas flectadas (Figura 10). El Contexto Funerario 2 se halló a una profundidad de $1.17 \mathrm{~m}$ en el sector sureste de la sepultura. En este entierro se depositaron dos individuos: el primero, adulto de sexo masculino en posición sentada y enterrado sin cabeza. Se encontraba vestido con una túnica rectangular monocroma sobre la cual se puso otra túnica, también monocroma, pero de forma semitrapezoidal. La túnica exterior, de color azul piedra y de forma semitrapezoidal, estaba decorada con cuatro hileras de cuatro rombos de color blanco, logrados por teñido por amarras. Como parte de la vestimenta del exhumado se encontró un taparrabo de color café y bandas laterales verdes. Como

\footnotetext{
24 Túnicas $\mathrm{n}^{\circ} 250(01)$ y n² 256 (01), según inventario del Proyecto FONDECYT No 1950071, actualmente depositadas en el IIAM.
}

ofrendas presenta varias bolsas: dos wayuñas y cuatro talegas decoradas con bandas de colores y listas ajedrezadas, además de dos chuspas que presentan decoración sólo con bandas de colores. Finalmente, cerca de la extremidad superior izquierda, se encontró una placa ancha de metal que podría corresponder a un brazalete (Correa 1998). Al lado del individuo adulto se encontró el esqueleto de un infante de $18 \pm 6$ meses asociado a tres túnicas, siendo la exterior de similares características a la del adulto. Frente al cráneo del niño se identificó una placa de metal muy delgada y al lado izquierdo del mismo una botella de cuerpo globular de color café rojizo. También como parte de la ofrenda se encontró una talega con decoración en bandas de color café, rojo y verde. Contamos con un fechado de 1055 DC de una botella del tipo Pica-Charcollo asociada al infante, que, sumado a las fechas de los contextos funerarios 1 y 3 , correspondientes a 980 y 1005 DC, y 1110 DC, respectivamente, y a los tipos de túnicas, bolsas y alfarería asociados (Agüero 1998; Cases 1997; Ayala y Uribe 1996, respectivamente), sitúan claramente a estas piezas hacia la primera mitad del Período Intermedio Tardío y dentro del Complejo Pica-Tarapacá.

En Chacance-2 encontramos otro ejemplar, similar al anterior, que forma parte de la exhibición permanente del Museo Municipal de María Elena. ${ }^{25}$ Esta túnica se encontró en la Tumba 5, un entierro doble en una tumba ampollar, en cuyo interior estaban los cuerpos superpuestos: un niño de cuatro a cinco años sobre un adulto senil, que a juzgar por la disposición de los cuerpos mismos y del ajuar habrían sido enterrados en la misma ocasión, no siendo posible determinar a qué cuerpo corresponden las piezas como ajuar (Castellón 1979-1981 Ms). Ambos se encuentran al interior de redes de lana. Sobre este hallazgo se encontraron tres estatuillas antropomorfas grandes, una de ellas bicéfala. El resto del ajuar estaba constituido por dos platos de cestería; aljaba de cuero; fragmentos de una huincha café claro; portaobjetos (cabezales de flecha); sonajera compuesta; cestería reutilizada con penacho y orejas de felino; gorro policromo con penacho de plumas tropicales; dos cestos decorados; dos platos de cestería; aljaba de cuero que conserva su asa de lana; faja monocroma; sandalias de cuero; bolsas-faja; casco de

\footnotetext{
25 Túnica s/nº. Museo Municipal de María Elena.
} 


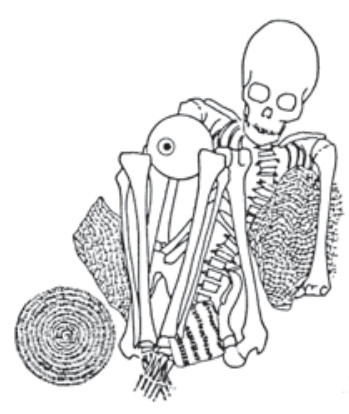

CONTEXTO 3

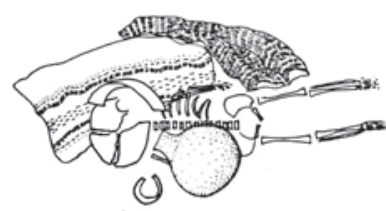

CONTEXTO 4

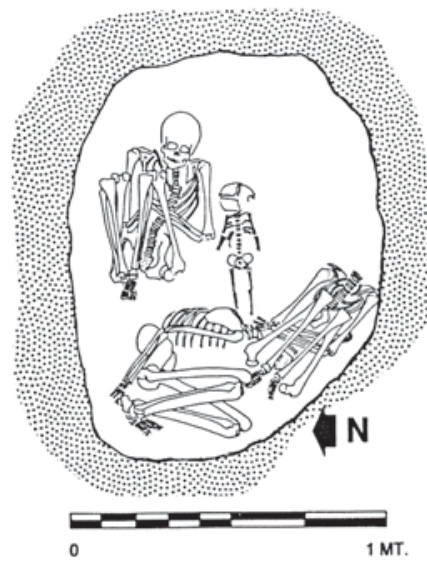

QUILLAGUA

02 QUI 01 CEMENTERIO ORIENTE SECTOR NE CUADRICULA B

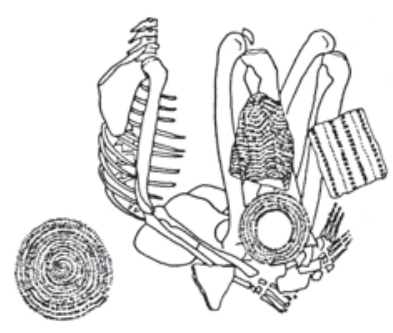

CONTEXTO 1

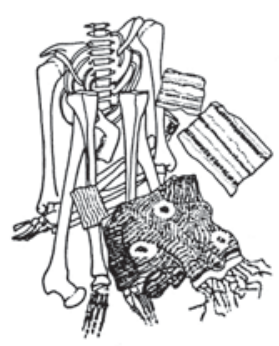

CONTEXTO 2

Figura 10. Túnicas 250 (01) y 256 (01) del Contexto Funerario 2 del Cementerio Oriente de Quillagua, Colección Museo Arqueológico R. P. Gustavo Le Paige, s. j.

cuero con bandas verticales rojas y verdes; dos ganchos de atalaje; 13 flechas completas y 13 fragmentadas; cuatro talegas; chuspa decorada; manta; pulseras de cuero; cerámica Dupont; mitad de un puсo; cencerros; túnica bicroma; dos tobilleras rojas; manta verde; charqui al interior de talega; mazorcas contenidas por talega; fragmentos de cactus; par de sandalias de cuero; restos de pescado; tres trozos de pulpo seco; fragmentos de madera de algarrobo; fragmentos de madera trabajada; cuero de pescado con carne adherida; huincha policroma; gorro policromo con orejas de felino; pluma de guacamayo; cuchara con tallado escalerado; pulsera de metal; aljaba de piel de jaguar; tobillera roja desarmada; tiesto globular de base plana con asas horizontales del tipo Rojo Violáceo; costal; fragmento textil café; siete flechas completas amarradas juntas; restos de camélido; fragmentos de cordelería; algarrobo y madera; faja policroma y faldellín; fragmento de textil bicromo con costura gruesa y faja de piel. Contamos con un fechado por termoluminiscencia de 625 DC, correspondiente a la vasija globular Rojo Violáceo (Agüero et al. 1997). Además, existe un fechado radiocarbónico de $930 \pm 50$ AP (aprox. 1170 DC) tomado por Mario Rivera sobre el cuerpo del adulto (Castellón com. pers. 1998). No hemos considerado definitorio el fechado TL en la asignación cronológica debido a que éste fue realizado con una dosimetría correspondiente 
a una media de sitios de Quillagua, otorgándole mayor importancia a la asignación al Período Intermedio Tardío temprano basada en los mismos argumentos y asociaciones que las túnicas de Quillagua (tipo de túnica, túnicas, bolsas y cerámica asociadas). Finalmente, el cementerio en sí, en cuanto emplazamiento y tipo de tumbas coincide con el registro existente para el período en el Loa (Agüero et al. 1997). Todo esto se confirma, con el fechado radiocarbónico obtenido por Rivera y por la forma semitrapezoidal de la túnica -que fue posible de observar luego del desenfardamiento del cuerpo del niño realizado en 1998 por W. Conklin- que la inserta en el Complejo PicaTarapacá de la Tradición Textil de Valles Occidentales (Figura 11).

En Tarapacá también hemos registrado túnicas y fragmentos de túnicas de este tipo provenientes del sitio Pica-8. ${ }^{26}$ Una de ellas, correspondiente a la flecadura, procede de la tumba 14 , sector B y se encuentra asociada a una talega en colores naturales, con varias reparaciones (Zlatar 1984). Otro ejemplar completo, proviene del mismo sitio y no tiene registro de asociaciones (Zlatar 1984). Esta última integra el mismo conjunto aunque, como señaláramos más arriba, representa una variación. ${ }^{27}$ Mantiene la estructura de "composición" más o menos constante, es decir, una pieza completa y una flecadura tejidas por separado y luego unidas por un encandelillado. Además, la técnica decorativa es la misma, con las salvedades de presentar sólo un rombo poco más abajo de la abertura para los brazos y una pequeña variación en la cantidad de tejido en faz de urdimbre de la flecadura y en el anudado que presentan los flecos (Figura 12). No obstante, las similitudes formales y técnicas estructurales la relacionan al Complejo Pica-Tarapacá. Procede de la tumba 5, sector D de Pica-8, donde se encuentra asociada a una chuspa, una espátula de hueso y una bolsa (Zlatar 1984: 47).

La asignación cronológica y cultural de estas tres piezas se ha basado en su pertenencia al Tipo 21

26 Túnica $\mathrm{s} / \mathrm{n}^{\circ}$ y flecadura $\mathrm{n}^{\circ} 0192$ (podría ser parte de túnica $\left.\mathrm{s} / \mathrm{n}^{\circ}\right)$, del inventario de Pica-8 realizado por Zlatar (1984). Depositado en el Instituto de Investigaciones Antropológicas de la Universidad de Antofagasta.

27 Túnica $n^{\circ} 0316$ del inventario de Pica-8 (Zlatar 1984). Depositado en el Instituto de Investigaciones Antropológicas de la Universidad de Antofagasta.

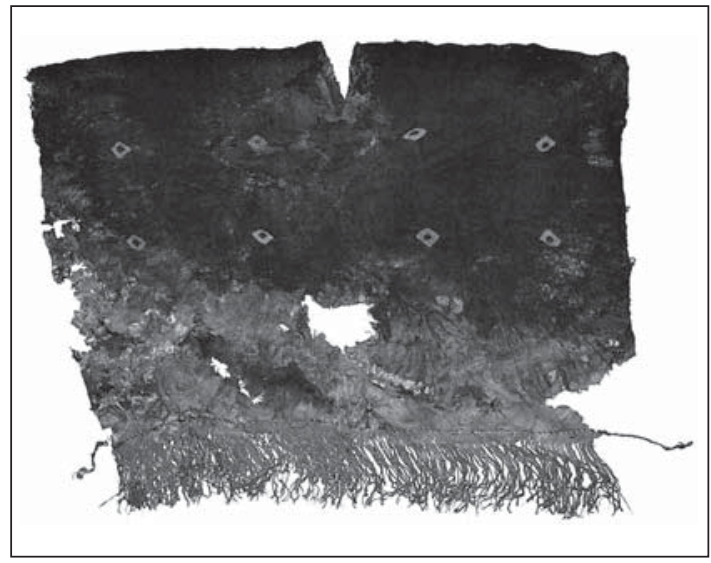

Figura 11. Túnica $s / n^{\circ}$, Tumba 5 , Chacance 2, Colección $\mathrm{Mu}$ seo Municipal de María Elena. (*) Ver agradecimientos.

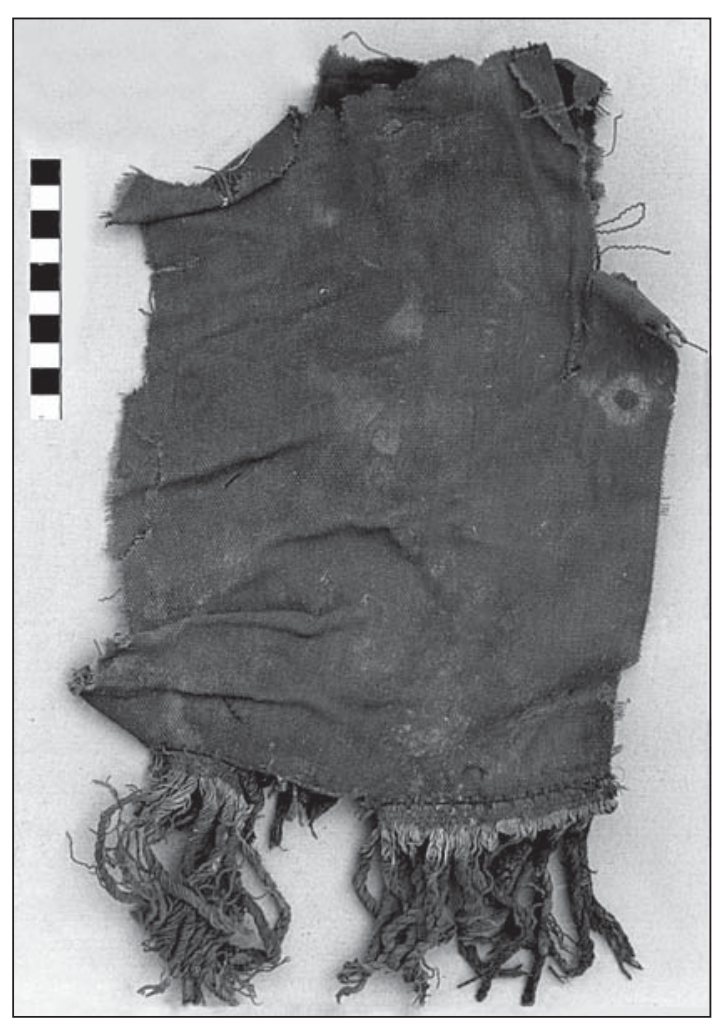

Figura 12. Túnica $n^{\circ} 0316$, Tumba 5 , Sector D, Pica-8, Colección Instituto de Investigaciones Antropológicas, Universidad de Antofagasta.

de túnicas definidas para el Complejo PicaTarapacá, por sus características formales y técnicas (Agüero 1998). Apoyan su asignación cronológica fechados radicarbónicos para el sitio Pica-8 que arrojan una media de 1000 DC (Zlatar 1984). 
Completa este conjunto un fragmento correspondiente a la parte inferior y a la flecadura de un ejemplar de este tipo de túnica. ${ }^{28}$ No obstante estar depositada en la Corporación Cultural y Turismo de Calama, suponemos que procede del sitio Pica-8, porque en el depósito se halló junto a otras piezas -tocados, faja y fragmentos de tapiceríamarcados como procedentes de ese cementerio.

También hemos considerado como perteneciente a este período a un taparrabo procedente de Topater-1, en Calama. ${ }^{29}$ Fue recuperado de la unidad A-1, pero salvo algunas bolsas pertenecientes a la misma unidad, no tenemos mayor información de sus asociaciones contextuales. Antes de describirlo, queremos aclarar que consideramos que se trata de un taparrabo y no de una inkuña, por las siguientes razones: a) porque presenta un cable como terminación en el vértice, además de un segundo cable a unos 10 ó $15 \mathrm{~cm}$ de éste, siendo ambos atributos característicos de este tipo de prendas; b) el patrón de descomposición de la pieza corresponde a aquella de los taparrabos, es decir, desintegrados al centro debido a los fluidos corporales; c) en Pica- 8 hemos registrado taparrabos que presentan los mismos atributos decorativos que las inkuñas.

Como ya señaláramos, la pieza está fragmentada, pero sus dimensiones actuales son $81 \mathrm{~cm}$ de largo por $50 \mathrm{~cm}$ de ancho. Corresponde a tejido plano en faz de urdimbre, elaborado con trama continua en hilados de camélido. En la orilla de urdimbre presenta un festón anillado sencillo, que termina en cordones. Para disponerlo como taparrabo, se usaron hilados blancos (Figura 13). En cuanto a su asignación cronológica, pensamos que posiblemente corresponda al Período Intermedio Tardío. Aunque Topater tiene fechados que lo insertan en el Formativo (Thomas et al. 1995; A. Benavente com. pers. 2000), hemos registrado otros textiles, principalmente bolsas correspondientes al Período Intermedio Tardío, algunas de las cuales provienen incluso de la misma unidad de recuperación (Cases 1997). A su vez, visualmente nos parece que este taparrabo tiene mayor relación con las túnicas de la primera mitad del Período Intermedio Tardío, que con los hilados teñidos por amarras

28 Fragmento de túnica s/n ${ }^{\circ}$. Corporación Cultural y Turismo de Calama.

29 Taparrabo s/n $\mathrm{n}^{\circ}$. Corporación Cultural y Turismo de Calama.

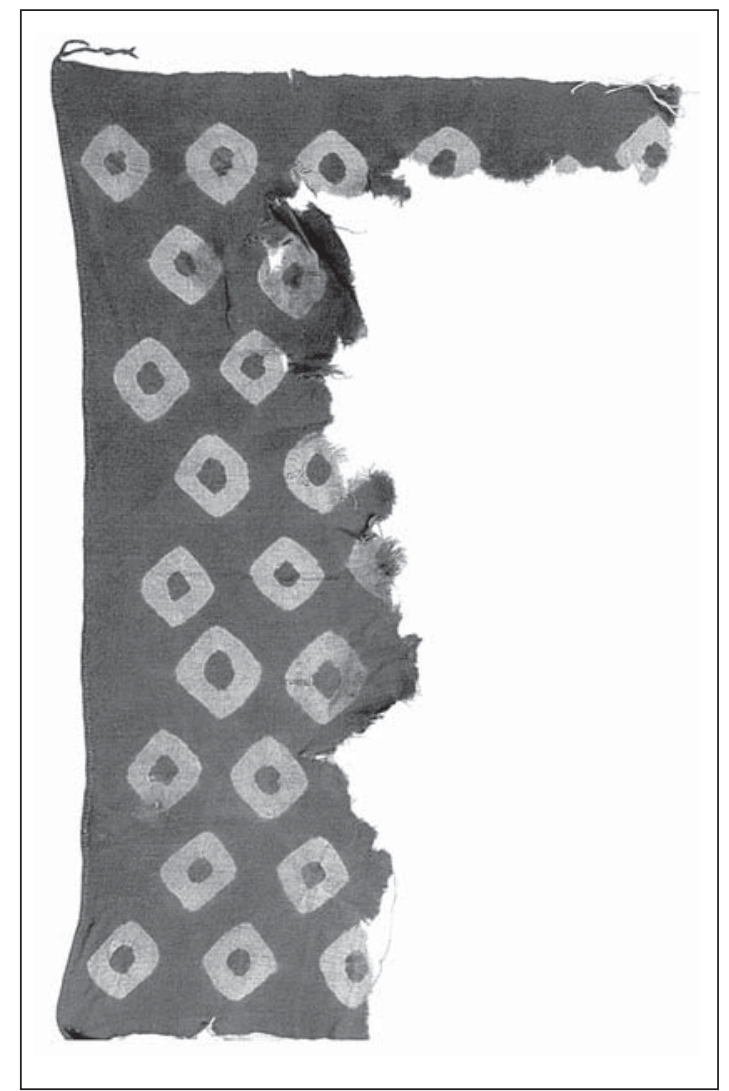

Figura 13. Taparrabo $s / n^{\circ}, A-1$, Topater-1, Colección Corporación Cultural y Turismo de Calama. (*) Ver agradecimientos.

registrados en Topater que hemos mencionado en relación al Formativo. Por otra parte, el uso de una trama continua sugiere una vinculación con la Tradición Valles Occidentales (Agüero 2000).

Finalmente, para el tercer grupo de piezas, de acuerdo a la disposición de estas cintas en una momia proveniente de Chacance-2, hemos asumido que son adornos para el cabello (Figura 14). Esta momia se encontró en la Tumba 1, correspondiente a un enterratorio de forma ampollar con peldaño, señalizada por tres piedras. Se identificó un sello de piedra y un textil que habría cumplido la misma función. El individuo se encontró en posición sentada a $50 \mathrm{~cm}$ de profundidad, cuyo material de relleno estaba mezclado con palomitas de maíz hasta los hombros. El ajuar se compone por restos de pescado; chuspa policroma con palomitas de maíz; chuspa policroma conteniendo harina de maíz; talega policroma con harina de maíz; talega policroma con palomitas de maíz; vichuña de hueso y fragmentos de otra vichuña; 


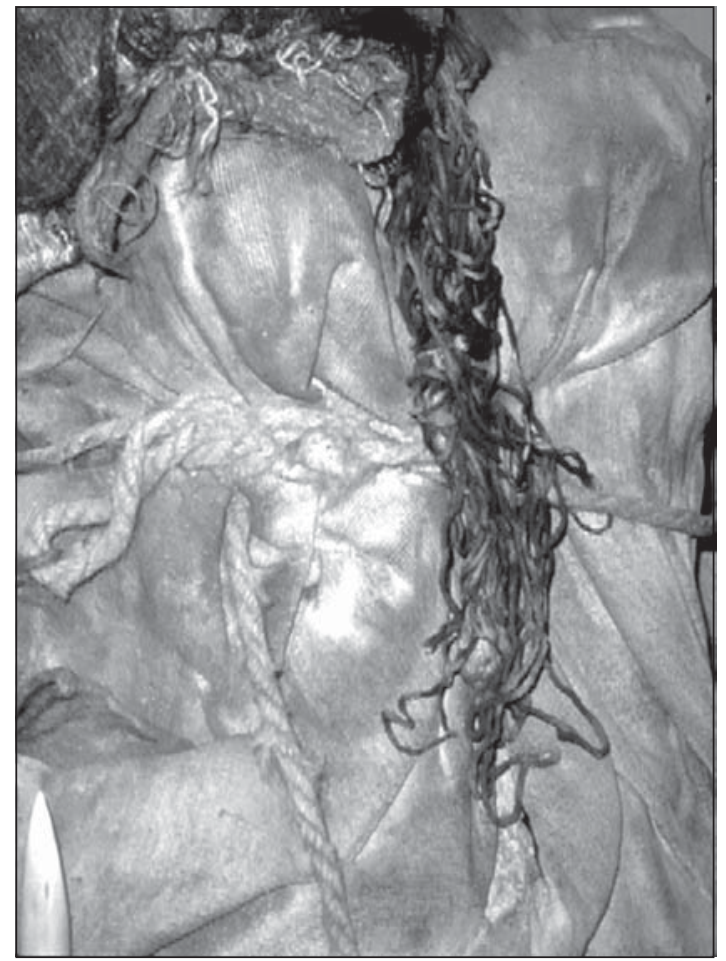

Figura 14. Detalle momia de la Tumba 1, Chacance 2, portando "cintas". Colección Museo Municipal de María Elena.

sandalia de cuero; seis fragmentos de madera; fragmento de asa pequeña color negro; fragmentos de cerámica Ayquina y Dupont; cordel de lana; cordel policromo (pasador de cuero); algarrobo; bolsa de anillada conteniendo fibra de camélido; bolsita anillada monocroma; taparrabo policromo; fragmento textil policromo; fragmento cordelería blanca; cordelería policroma; bolsa (con calabaza pirograbada al interior); fragmentos de pala; restos de pulpo; cántaro globular Rojo Violáceo; calabaza pirograbada reparada con hilados; tiesto de cestería con motivos zoo y antropomorfo; collar compuesto de semillas y turquesa y collar de hilos rojos.

Para esta tumba se cuenta con un fechado de 825 DC tomado sobre cerámica Ayquina. La fecha es ligeramente más temprana que las existentes para el Período Intermedio Tardío (la dosimetría no fue realizada específicamente para este sitio, sino que corresponde a una media de sitios de Quillagua), pero tanto las bolsas registradas (Cases 1997), como el material cerámico corresponden a un momento temprano del período (Ayala y Uribe 1996; Uribe 2002).
Otra pieza de este grupo procede de la tumba 4758 del Cementerio de San Pedro de Atacama, según notas de Le Paige. ${ }^{30}$ No contamos con información de asociaciones contextuales; no obstante, Renard (1997: 295-296) describe dos piezas más, también de San Pedro de Atacama, un conjunto procedente de Doncellas y otro de Susques (Jujuy), del Noroeste Argentino. ${ }^{31}$ De la misma zona, Rolandi de Perrot (1973 y 1979) describe ejemplares de este tipo provenientes de Tastil y Doncellas.

Por otra parte, hemos registrado este tipo de estructuras, todas teñidas por amarras, en Pica-8, en el Cementerio Oriente de Quillagua, en la Colección Latcham del Museo Nacional de Historia Natural, también procedente de dicha localidad, todos correspondientes a los inicios del Período Intermedio Tardío. Sabemos también que están presentes en Camarones-8 (J. Correa com. pers., 1999), posiblemente del sector basural, correspondiente al Arcaico (Muñoz et al. 1993), aunque no debe descartarse la posibilidad de que corresponda a los materiales recuperados del sector del Intermedio Tardío. No obstante lo anterior, está también en piezas que formaban parte de turbantes durante el Formativo, al menos en el cementerio de Pisagua-D (Agüero 1995), lo que ampliaría su expansión en el tiempo al menos a unos 1000 años AC.

Con todo, la asignación cultural y cronológica nos merece dudas, ya que encontramos este tipo de estructuras teñidas por amarras en sitios correspondientes al Arcaico, Formativo, inicios del Período Intermedio Tardío y Tardío (Doncellas), con una dispersión temporal y espacial muy amplia, siendo su asignación al Período Intermedio Tardío la más clara.

\section{Comentarios Finales}

De acuerdo a los materiales disponibles es evidente que la técnica del teñido por amarra está presente en el Norte Grande desde finales del Arcaico hasta la primera mitad del Período Intermedio Tardío.

30 Cinta $n^{\circ} 18298$, depositada en el IIAM.

31 Cintas n $^{\circ} 22584$ (procedente de San Pedro de Atacama), $n^{\circ}$ 42-668 (procedente de Doncellas) y n² 27-241 (Susques), depositadas en el Museo Etnográfico Juan B. Ambrosetti de la Universidad de Buenos Aires; $n^{\circ} 150$ (procedente de San Pedro de Atacama), depositada en el Museo de Tilcara. 
Ya en el Arcaico Tardío (1500-1000 AC) encontramos el primer antecedente de esta técnica de tintorería, en sitios como Quiani-7 y Camarones15D, donde se recuperaron cuerpos con turbantes con hilados teñidos por amarra. En este primer momento, la técnica se empleó sólo en hilados, principalmente bouttonnés, que se usaron como accesorios y no en la realización de piezas. De ello da cuenta una momia Chinchorro tardía, cuyo turbante posee un elemento de este tipo, realizado en hilado bouttonné y sus materiales asociados -una manta en técnica de torzal en hilados de camélido, listada, con cadeneta estructural y tramas en torzal en el encabezamiento de urdimbrecorresponden a tipos textiles bien documentados para el Formativo Temprano costero. Aunque también es un hallazgo aislado, hay que destacar la presencia de un hilado teñido por amarra en el sitio Topater, cuyos fechados lo sitúan más bien en el Formativo Tardío; sin embargo, ciertos textiles de dicho cementerio lo relacionan con la quebrada de Camarones e incluso con el valle de Azapa (Agüero y Cases 2004).

Posteriormente, en el Formativo (1000 AC-500 DC) el mismo tipo de hilados se emplea en la confección de piezas, tales como faldellines, presentes al menos en Camarones-15 AB. Nuevamente, hallamos vinculaciones con el Loa Medio, a través del hallazgo en Topater de faldellines que tienen el mismo patrón de construcción, en hilados bouttonné, pero sin decoración por esta técnica.

Durante el Período Medio (500-1000 DC), parece existir un hiato, al menos en un momento inicial, porque hacia finales del período e inicios del Intermedio Tardío, volvemos a registrar en los Valles Occidentales una pieza decorada en esta técnica. Esta corresponde a un poncho de Az-6, para el que proponemos un carácter intrusivo, teniendo su origen probablemente en la Costa Sur del Perú. El poncho, sin duda, es totalmente atípico: está construido a partir de una sola pieza, y tanto el cuerpo en sí como los flecos, que forman parte del mismo paño, tienen como decoración una lista blanca sobre el fondo rojo intenso. Encontramos aquí no sólo un único color, como en aquella de Pica-8, sino también una sola pieza o paño tejido, que desde el punto de vista de la estructura textil es bastante más simple. La única relación técnica con las otras piezas del período la constituye la flecadura estructural. Vemos, entonces, que en este período, en Arica y Tarapacá la técnica está escasamente representada en relación a desarrollos de otros territorios, donde la reserva por amarra presenta un mayor nivel de expertismo.

Sin duda, el gran conjunto de prendas tejidas y teñidas por amarra del Período Medio se concentra en el territorio atacameño, específicamente en San Pedro ( $\mathrm{n}=9$ ), y uno en Chiu Chiu (Lindberg 1963). Se trata de túnicas y mantas construidas por la unión de módulos rojo/azul u ocre/azul a través de la técnica de urdimbres discontinuas. $\mathrm{La}$ distribución de estas prendas se restringe al territorio de Atacama (con la excepción de la prenda encontrada en Pica-Quisma, pero de procedencia atacameña), y como era de esperar, todas ellas utilizan tramas múltiples. Los contextos y una fecha de 640 DC asignaría a estas piezas a la segunda mitad del Período Medio en Atacama. La distribución de las piezas coincide con la información que se maneja para los inicios del Período Intermedio Tardío Inicial, cuando la frontera de las poblaciones atacameñas, desde el Loa Medio e Inferior, se circunscribe hacia el margen sur de este río (Aguiero et al. 1997).

No podemos dejar de hacer notar que, si atendemos muchas de las asignaciones culturales que se han publicado, vemos que existe una tendencia a identificar como "Tiwanaku" a casi todos los textiles que presentan motivos "escalerados" y a tomar al pie de la letra lo dicho por Ulloa en 1982. No obstante, nuevas investigaciones han arrojado resultados algo diferentes. Los textiles Tiwanaku registrados en Chile corresponden a Tiwanaku III y IV, es decir, a aquellos que muestran una iconografía claramente vinculada a la representada en la escultura lítica del sitio tipo en las cercanías del lago Titicaca. El resto de los tejidos asignados a Tiwanaku se relaciona más bien a expresiones locales del Período Medio en Azapa y en Atacama, y no puede asignarse a creaciones de esa población altiplánica (Agüero 2000).

También queremos mencionar que no existen datos concretos para asignar a Tiwanaku la técnica del teñido por amarra, ya que, en primer lugar, cuenta con antecedentes en contextos costeros arcaicos y formativos del norte de Chile. En segundo lugar, el argumento utilizado por Oakland (1986) y por Torres y Conklin (1995) respecto a que los círculos observados en la vestimenta de un monolito del sitio tipo podrían ser una representación de esta técnica, no nos parece acertado, ya que no 
existe ningún tejido teñido por amarra ni en el altiplano circumtiticaca ni en Cochabamba, ambos centros de producción de ese Estado altiplánico, y donde sí se han conservado otros tejidos. Cabe señalar el hallazgo del "Tesoro de San Sebastián" en Cochabamba (que incluía una túnica y falda tejida con aplicaciones de círculos de oro) nos parece una comparación más acertada (Money 1991). Más aún, ni en el gran enclave Tiwanaku en Moquegua, ni en Ilo (valle del Osmore, sur del Perú), hemos registrado textiles de este tipo, y de donde sería lo más probable que provinieran los tejidos teñidos por amarra de Azapa y Tarapacá, si fueran Tiwanaku (Uribe y Agüero 2002).

Como muestra el registro arqueológico durante el Período Medio e Intermedio Tardío, San Pedro de Atacama se comporta de manera excepcional. Así, las túnicas que proceden de esos oasis muestran mayor complejidad técnica en su estructura y en sus terminaciones. Por ejemplo, tenemos piezas con ocho a 16 módulos de colores alternados, esta última correspondiente a una manta, además con un sector central con motivos de cruces y escalerados logrados por urdimbres discontinuas. Entre las terminaciones tenemos las costuras con encandelillado, puntada en ' 8 ' y puntada zigzag envuelta. Las aberturas están reforzadas con un festón simple y la túnica 3937 presenta un refuerzo de la flecadura a través de una cadeneta. La túnica 3945-1 muestra una cadeneta estructural en el encabezamiento urdimbre (lo que hasta el momento sólo habíamos registrado en textiles del Formativo). Además, esta túnica tiene un rectángulo de $4 \mathrm{~cm}$ de ancho y $1 \mathrm{~cm}$ de largo hecho en puntada corrida doble lineal, como refuerzo en el vértice de la abertura para el cuello. Aparte de esto, en San Pedro se encuentra la única túnica que presenta motivos figurativos Aguada, y los únicos registros de mantas de la muestra. Como sucede en Atacama, todas las prendas que registramos utilizan tramas múltiples, insertándose de inmediato en la Tradición Textil de Atacama.

Finalmente, durante el Período Intermedio Tardío, encontramos la mayor concentración de tejidos decorados por esta técnica, correspondientes al Complejo Pica-Tarapacá, dentro de la Tradición Textil de Valles Occidentales. Identificamos tres conjuntos de piezas teñidos por amarras.

El primero corresponde a túnicas construidas por la unión longitudinal de dos paños, uno azul y uno rojo, en una prenda semitrapezoidal en Azapa, una rectangular en Bajo Molle (costa de Tarapacá), ambas con utilización de una trama continua y (probablemente) una de San Pedro de Atacama $\left(n^{\circ}\right.$ 3945-1) con utilización de tramas múltiples. Los fechados y contextos sitúan a las primeras en la primera mitad del Período Intermedio Tardío.

El segundo, sin duda, es el grupo más coherente. Se trata de túnicas constituidas por dos partes: cuerpo y flecadura, ambas realizadas en forma independiente y unidas por un encandelillado. No presentan dudas en cuanto a su asignación cronológica a la primera mitad del Período Intermedio Tardío. Están bien documentadas a través de los contextos y fechados disponibles. Se distribuyen en forma pareja, aunque escasa -uno a dos ejemplares por sitio- en Arica y Tarapacá hasta el Loa, estando ausentes en San Pedro de Atacama. Esta distribución se relaciona con una expansión del Complejo Pica-Tarapacá hacia el sur (Loa), situación bien documentada, tanto a través de material textil como cerámico en Quillagua, durante esta parte del Período Intermedio Tardío (Agüero et al. 1997). En efecto, vemos estas túnicas tanto en Arica, Pica, Quillagua y Chacance, no registrándose ningún ejemplar de este tipo más allá de dicho sitio, lo que coincide con que el hecho de que el río Loa haya constituido una frontera entre los territorios de Tarapacá y Atacama (Agüero et al. 1997).

El tercer grupo consiste en cables unidos por un hilado (costura) y luego teñidos por amarras. Nuevamente encontramos homogeneidad en cuanto a la técnica de manufactura y decoración. Este grupo correspondería claramente al Período Intermedio Tardío por las mismas razones que las otras piezas de este período: contextos y fechados consistentes. Sin embargo, existe registro de este tipo de estructuras, también teñidas por amarras, en sitios correspondientes al Arcaico (Camarones-8 basural) y Formativo (Pisagua-D), lo que ampliaría su expansión temporal. Por otra parte, es este el tipo de piezas que goza de la mayor distribución espacial: de Camarones al Loa Inferior, y desde la costa de Chile hasta el Noroeste Argentino, lo que dificulta su asignación cultural.

La última pieza es un taparrabo que hemos asignado a este período - por los materiales presentes en la misma unidad de recolección y por el uso de una sola trama-, sugiriendo relaciones con la Tradición Textil de Valles Occidentales. 
Por otra parte, todas las prendas tejidas revisadas presentan ciertas particularidades coherentes con su lugar de procedencia, permitiéndonos suponer una factura local. Así, en Azapa hay una túnica de forma semitrapezoidal, y tanto en Arica como en Tarapacá utilizan una trama continua, como es lo habitual en la Tradición de Valles Occidentales. Tarapacá por su parte se comporta de la manera esperada, esto es, compartiendo elementos tanto de las subáreas de Valles Occidentales (Azapa) como de la Circumpuneña (Atacama). Lo último se observa en la túnica de Pica-Quisma. Tanto en la muestra que tenemos para Azapa como para Tarapacá, es notoria la ausencia de la técnica de urdimbres discontinuas (salvo la túnica PicaQuisma). Por su parte, San Pedro de Atacama entrega cuatro túnicas, todas de dimensiones más pequeñas que las anteriores, rectangulares, y con utilización de tramas múltiples y de la técnica de urdimbres discontinuas.

Al menos, en las piezas que hemos documentado, las técnicas con que están confeccionadas o terminadas parecen ser menos complejas en la Subárea de Valles Occidentales que en la Circumpuneña. La mayoría de las túnicas de Arica, Tarapacá y el Loa están confeccionadas con un solo paño tejido, o bien, con dos paños tejidos cosidos a los lados y al centro dejando aberturas para introducir brazos y cuello. Las uniones laterales y centrales son simples encandelillados o "espina de pescado" sin refuerzos de las aberturas para brazos y cuellos ni en sus vértices. Salvo en la túnica de Pica-Quisma -similar a las de San Pedro- no está presente la técnica de urdimbres discontinuas.

Para terminar, un último punto, que nos parece interesante de resaltar, es que los lugares en que se ha registrado el teñido por amarra corresponden a zonas que tienen una gran interacción con otras: Azapa con los desarrollos de la costa sur peruana y Atacama con los del Noroeste Argentino, habiendo en ambos un alto nivel de expertismo en cuanto al uso de esta técnica. A su vez, cronológicamente, los hallazgos en territorio chileno tienen una cierta correspondencia con aquellos del Area Central Andina. De hecho, resulta notable que si aceptamos que la técnica de teñido por amarra fue usada por poblaciones Chinchorro tardías, en la costa de Arica, en fechas cercanas al $1000 \mathrm{AC}$, las primeras manifestaciones de esta técnica en nuestro territorio se sitúa en forma casi paralela a aquellas registradas para la misma técnica en Chavín, y más sorprendente aún, a textiles pintados en técnica de reserva en Carhua, en la Costa Sur del Perú, fechados hacia 900-700 AC. Contemporáneos al Período Medio, e incluso traslapándose con el Formativo, encontramos textiles Nasca (300-700 DC) y Nasca-Wari (600-1000 DC) teñidos por amarra, en la Costa Sur del Perú. Dentro de estos textiles, existen atributos presentes en nuestro registro, como el uso de camélido, la flecadura estructural también con reserva y la presencia de tejidos en módulos (urdimbres discontinuas). En períodos posteriores la técnica también está presente en las culturas Chancay (1100-1400 DC) y Chimú (11001532 DC), en la Costa Central y Norte del Perú, respectivamente, lo que cronológicamente sitúa a dichos hallazgos en forma relativamente contemporánea a los conjuntos que hemos reconocido para la primera mitad del Período Intermedio Tardío en el Norte Grande de Chile.

Agradecimientos Queremos expresar nuestra gratitud a Soledad Hoces de la Guardia y Paulina Brugnoli por habernos invitado a participar en la documentación de las piezas que dieron origen a esta publicación, y a Pilar Alliende, del Museo Chileno de Arte Precolombino, por permitirnos utilizar fotografías de la publicación "Amarras: El arte de teñir en los Andes Prehispánicos", catálogo de la exposición homónima realizada por dicha institución en noviembre de 1999, las que se encuentran individualizadas por $(*)$ en este artículo. Las fotografías fueron tomadas por Claudia del Fierro, quien también realizó la diagramación de las figuras. Asimismo queremos agradecer a las instituciones depositarias de las piezas referidas por autorizar su estudio y publicación. 


\section{REFERENCIAS CITADAS}

AGÜERO, C., 1992. Ms. Sobre terminologías textiles. De los Hilados. Manuscrito en poder de la autora.

-1994. Madejas, hilados y pelos: Los turbantes del Formativo Temprano en Arica, norte de Chile. Tesis para optar al Título de Arqueólogo, Depto. de Antropología, Facultad de Ciencias Sociales, Universidad de Chile, Santiago.

—1995. El cementerio "Protonazca de Pisagua". Estudio de la textilería. Hombre y Desierto 9: 7-16.

_ 1998. Tradiciones textiles de Atacama y Tarapacá presentes en Quillagua durante el Período Intermedio Tardío. Boletín del Comité Nacional de Conservación Textil 3: 103-128.

-2000. Las tradiciones de Tierras Altas y de Valles Occidentales en la textilería arqueológica del valle de Azapa. Chungara 32 (2): 217-226.

AGÜERO, C. y B. CASES, 2004. Quillagua y los textiles formativos del Norte de Chile. Chungara, volumen especial, pp. 59-77.

AGÜERO, C., M. URIBE, P. AYALA y B. CASES, 1997. Variabilidad Textil en el valle de Quillagua: Una aproximación a la etnicidad. Estudios Atacameños 14: 263-290.

ALLISON, M., G. FOCACCI, B. ARRIAZA, V. STANDEN, M. RIVERA y J. LOWENSTEIN, 1984. Chinchorro: Momias de preparación complicada. Métodos de momificación. Chungara 13: 155-173.

ARRIAZA, B., 1994. Tipología de las momias Chinchorro y evolución de las prácticas de momificación. Chungara 26 (1): 11-24.

_-1995. Chinchorro bioarchaeology: Chronology and mummy seriation. Latin American Antiquity 6 (1): 35-55

AYALA, P. y M. URIBE, 1996. Caracterización de dos tipos cerámicos ya definidos: Charcollo y Chiza Modelado. Boletín de la Sociedad Chilena de Arqueología 22: 24-27.

BRUGNOLI, P. y S. HOCES DE LA GUARDIA, 1999. Las imágenes en color del tintorero de los Andes. En Shibori: El arte de teñir con amarras, I. Dusi, Y. Wada, M. Bravo, M. Correa, T. Grant y P. Velasco (Eds.), pp. 15-23. Museo Nacional de Bellas Artes, Santiago.

CASES, B., 1997. Bolsas de Quillagua: Una sistematización del universo textil contenedor. Contribución Arqueológica 5: 83-117.

CASES, B. y A. M. ROJAS, 2001. Un planteamiento experimental de replicación: Registro y conservación preventiva de una momia Chinchorro Tardía. Chungara 33 (1): 107-111.

CASTELlON, C., 1979-1981 Ms. Diarios de terreno e inventario del Museo de María Elena.
CORREA, J., 1998. Descripción y análisis de diseño de los tejidos del Cementerio Oriente del valle de Quillagua. Boletín del Comité Nacional de Conservación Textil 3: 129-144.

DAUELSBERG, P., 1974. Excavaciones arqueológicas en Quiani. Chungara 4: 7-38.

ESPOUEYS, O., M. URIBE, A. ROMAN y A. DEZA, 1995. Fechados por termoluminiscencia para cerámica de estilo Tiwanaku de Arica. Hombre y Desierto 9: 31-54.

LINDBERG, I., 1963. Tejidos y adornos de los cementerios Quitor 2, 5 y 6 de San Pedro de Atacama. Revista Universitaria (Universidad Católica), año XLVIII: 195-202.

LLAGOSTERA, A., 1995. El componente cultural Aguada en San Pedro de Atacama. Boletín del Museo Chileno de Arte Precolombino 6: 9-34.

MONEY, M., 1991. El “Tesoro de San Sebastián”: Una tumba importante de la cultura Tiwanaku. Kava, Band 11, Beiträge zur Allgemeinen und Vergleichenden Archäologie, pp. 189-198.

MORAGAS, C., 1995. Desarrollo de las comunidades prehispánicas del litoral Iquique-desembocadura río Loa. Hombre y Desierto 9: 65-80.

MUÑOZ, I., R. ROCHA y S. CHACON, 1991. Camarones 15. Asentamiento de pescadores correspondiente al Arcaico y al Formativo. Actas del XI Congreso de Arqueología Chilena, T. II: 1-24. Santiago 1988.

MUÑOZ, I., B. ARRIAZA y A. AUFDERHEIDE, 1993. El poblamiento Chinchorro: Nuevos indicadores bioantropológicos y discusión en torno a su organización social. En Acha-2 y los orígenes del poblamiento humano en Arica, I. Muñoz, B. Arriaza y A. Aufderheide (Eds.), pp. 107-132. Ediciones Universidad de Tarapacá, Arica.

OAKLAND, A., 1986. Tiwanaku textile style from the South Central Andes, Bolivia and North Chile. Ph. D. Dissertation. The University of Texas at Austin, Austin.

1992. Textiles and ethnicity: Tiwanaku in San Pedro de Atacama, North Chile. Latin American Antiquity 3 (4): 316-340.

-1994. Tradición e innovación en la prehistoria andina de San Pedro de Atacama. Estudios Atacameños 11: 109-120.

PAUL, A., 1983. The symbolism of Paracas turbans: A consideration of style, serpents and hair. Nawpa Pacha 20: $41-60$

RENARD, S., 1997. Objetos textiles, pasos y caminantes trasandinos. Piezas similares y rasgos comunes en textiles arqueológicos de Argentina y Chile. Estudios Atacameños 14: 291-306. 
RIVERA, M., P. SOTO, L. ULLOA y D. KUSHNER, 1974. Aspectos sobre el desarrollo tecnológico en el proceso de agriculturación en el norte prehispánico, especialmente en Arica (Chile). Chungara 3: 79-107.

ROLANDI DE PERROT, D., 1973. Los textiles tastileños. En Tastil: Una ciudad preincaica argentina, E. Cigliano (Ed.), pp. 229-402. Ediciones Cabargón, Buenos Aires.

_-1979. Los tejidos de Río Doncellas, Departamento Cochinoca, provincia de Jujuy. Actas de las Jornadas de Arqueología del Noroeste Argentino, pp. 22-73. Buenos Aires.

SANHUEZA, J., 1985. Poblaciones tardías en playa Los Verdes, costa sur de Iquique, I Región, Chile. Chungara 14: 45-60.

SCHIAPPACASSE, V. y H. NIEMEYER, 1984. Camarones-14: Descripción y análisis interpretativo de un sitio arcaico temprano en la quebrada de Camarones. $\mathrm{Pu}$ blicación Ocasional Museo Nacional de Historia Natural 41.

SCHIAPPACASSE, V., A. ROMAN, I. MUÑOZ, A. DEZA y G. FOCACCI. 1991. Cronología por termoluminiscencia de la cerámica del extremo norte de Chile: Primera parte. Actas del XI Congreso Nacional de Arqueología Chilena, T. II: 43-60. Santiago 1988.

SINCLAIRE, C., 1998. Los gorros de cuatro puntas de la colección arqueológica Manuel Blanco Encalada: Tipología y secuencia para el valle de Azapa, Arica. Boletín del Comité Nacional de Conservación Textil 3: 103-128.
THOMAS, C., A. BENAVENTE, I. CARTAJENA y G SERRACINO, 1995. Topater, un cementerio temprano: Una aproximación simbólica. Hombre y Desierto 9: 159-173.

TORRES, E., C. CLEMENT, N. CLARK y J. C. TELLO, 1990. Un entierro precerámico doble en Villa del Mar, Ilo: Informe preliminar. Gaceta Arqueológica Andina 18/19: 59-64.

TORRES, C. y W. CONKLIN, 1995. Exploring the San Pedro de Atacama / Tiwanaku relationship. En Andean art: Visual expression and its relations to Andean beliefs and values, vol. 13, P. Dransart (Ed.), pp. 78-108. Worlwide archaeology series, Gran Bretaña.

ULLOA, L., 1982 a. Evolución de la industria textil prehispánica en la zona de Arica. Chungara 8: 97-108.

__ 1982 b. Estilos decorativos y formas textiles de poblaciones agromarítimas en el extremo norte de Chile. Chungara 8: 109-136.

URIBE, M., 2002. Sobre alfarería, cementerios, fases, procesos y la construcción de Atacama en la prehistoria Tardía (800-1600 DC). Estudios Atacameños 22: 7-31.

URIBE, M. y C. AGÜERO, 2002. Alfarería, textiles, y la integración del Norte Grande de Chile a Tiwanaku. Boletín de Arqueología PUCP 5: 397-426.

WISE, K., 1995. La ocupación Chinchorro en Villa del Mar, Ilo, Perú. Gaceta Arqueológica Andina 24: 135-149.

ZlATAR, V., 1984. Cementerio de Pica-8. Universidad de Antofagasta, Facultad de Educación y Ciencias Humanas, Instituto de Investigaciones Arqueológicas y Restauración monumental, Antofagasta. 